\title{
CryoSat-2 delivers monthly and inter-annual surface elevation change for Arctic ice caps
}

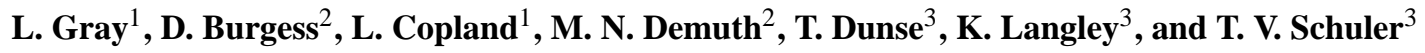 \\ ${ }^{1}$ Department of Geography, University of Ottawa, Ottawa, K1N 6N5, Canada \\ ${ }^{2}$ Natural Resources Canada, Ottawa, Canada \\ ${ }^{3}$ Department of Geosciences, University of Oslo, Oslo, Norway \\ Correspondence to: L. Gray (laurence.gray@sympatico.ca)
}

Received: 29 April 2015 - Published in The Cryosphere Discuss.: 26 May 2015

Revised: 15 August 2015 - Accepted: 3 September 2015 - Published: 25 September 2015

\begin{abstract}
We show that the CryoSat-2 radar altimeter can provide useful estimates of surface elevation change on a variety of Arctic ice caps, on both monthly and yearly timescales. Changing conditions, however, can lead to a varying bias between the elevation estimated from the radar altimeter and the physical surface due to changes in the ratio of subsurface to surface backscatter. Under melting conditions the radar returns are predominantly from the surface so that if surface melt is extensive across the ice cap estimates of summer elevation loss can be made with the frequent coverage provided by CryoSat-2. For example, the average summer elevation decreases on the Barnes Ice Cap, Baffin Island, Canada were $2.05 \pm 0.36 \mathrm{~m}$ (2011), $2.55 \pm 0.32 \mathrm{~m}$

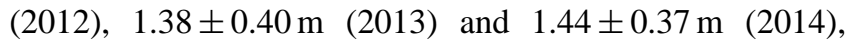
losses which were not balanced by the winter snow accumulation. As winter-to-winter conditions were similar, the net elevation losses were $1.0 \pm 0.20 \mathrm{~m}$ (winter 2010/11 to winter 2011/12), $1.39 \pm 0.20 \mathrm{~m} \mathrm{(2011/12} \mathrm{to} \mathrm{2012/13)} \mathrm{and}$ $0.36 \pm 0.20 \mathrm{~m}(2012 / 13$ to $2013 / 14)$; for a total surface elevation loss of $2.75 \pm 0.20 \mathrm{~m}$ over this 3 -year period. In contrast, the uncertainty in height change from Devon Ice Cap, Canada, and Austfonna, Svalbard, can be up to twice as large because of the presence of firn and the possibility of a varying bias between the true surface and the detected elevation due to changing year-to-year conditions. Nevertheless, the surface elevation change estimates from CryoSat for both ice caps are consistent with field and meteorological measurements.
\end{abstract}

\section{Introduction}

Recent evidence suggests that mass losses from ice caps and glaciers will contribute significantly to sea level rise in the coming decades (Meier et al., 2007; Gardner et al., 2013; Vaughan et al., 2013). However, techniques to measure the changes of smaller ice caps are very limited: Satellite techniques, such as repeat gravimetry from GRACE (Gravity Recovery and Climate Experiment), favour the large Greenland or Antarctic Ice Sheets, while ground and airborne experiments sample conditions sparsely in both time and space. Satellite laser altimetry (ICESat; Ice, Cloud, and land Elevation Satellite launched by the US National Aeronautics and Space Administration, NASA) was used between 2003 and 2009 but the results were limited by both laser lifetime and atmospheric conditions. NASA's follow-on mission (ICESat 2, Abdalati et al., 2010) is currently scheduled for launch in 2017, but until then CryoSat-2 (CS2), launched by the European Space Agency (ESA) in 2010, provides the only highresolution satellite altimeter able to routinely measure small ice caps and glaciers. The new interferometric (SARIn) mode of CS2 (Wingham et al., 2006) has important new attributes in comparison to previous satellite radar altimeters: delayDoppler processing (Raney, 1998) permits a relatively small ( $\sim 380 \mathrm{~m}$ ) along-track resolution (Bouzinac, 2014), while the cross-track interferometry (Jensen, 1999) provides information on the position of the footprint centre. Here we show that the SARIn mode of CS2 can measure annual height change of smaller Arctic ice caps, and even provide estimates of summer melt on a monthly time frame. 
To test and validate the CS2 altimeter, ESA developed the airborne ASIRAS Ku-band $(13.5 \mathrm{GHz})$ radar altimeter. ASIRAS has been operated during field campaigns under the CryoSat Validation Experiment (CryoVex) at selected sites before and after the launch of the satellite. One of the most interesting revelations of the ASIRAS data has been the demonstration of variability in relative surface and subsurface returns in a variety of locations including Devon Ice Cap in Canada, Greenland and Austfonna in Svalbard (Hawley et al., 2006, 2013; Helm et al., 2007; Brandt et al., 2008; De la Pena et al., 2010). The time variation of the ASIRAS return signals from the surface and near surface (the "waveforms") can and does vary significantly from year-to-year at the same geographic position, and in any one year with changing position across the ice cap. During cold conditions in spring, the maximum return need not be from the snow surface, but could be from the previous summer surface, or strong density contrasts within the snow pack such as those manifested by buried weathering crusts or refrozen percolating meltwater (e.g. Bell et al., 2008). Changes in snowpack characteristics, dependent on past meteorological conditions, could therefore affect the relative strength of the surface and volume component of the CS2 return signal and affect the bias between the elevation measured by CS2 and the true surface.

In this study we use all available SARIn data from July 2010 to December 2014 to undertake the first systematic measurement by spaceborne radar of elevation change on a variety of ice caps across the Canadian and Norwegian Arctic (Fig. 1) representing a wide range of climate regimes. Emphasis is placed on CS2 results from Devon and Austfonna as both ice caps were selected by ESA as designated calibration and/or validation sites, and a wide range of ground and airborne validation data sets are available. SARIn data are also used to measure height changes on Penny, Agassiz and Barnes ice caps to illustrate the wide applicability of the method in areas where there is less data available for surface validation. Together with the recent CS2 work on Greenland and Antarctica (McMillan et al., 2014a; Helm et al., 2014), this illustrates the power of the new interferometric mode of the CS2 altimeter to provide useful information in an allweather, day-night situation.

Our emphasis in this paper is to demonstrate that CS2 can measure elevation and elevation change on relatively small ice caps, even with differing surface conditions, and for some on a monthly timescale. The many complications associated with converting the CS2 elevation change data to an ice cap wide mass balance will be treated in future papers.

\section{Study areas}

We begin by describing the two ice caps, Devon and Austfonna, which were part of the CryoVex campaigns and which have a wide range of surface reference data. Then we discuss conditions on Barnes, Agassiz and Penny ice caps. Although

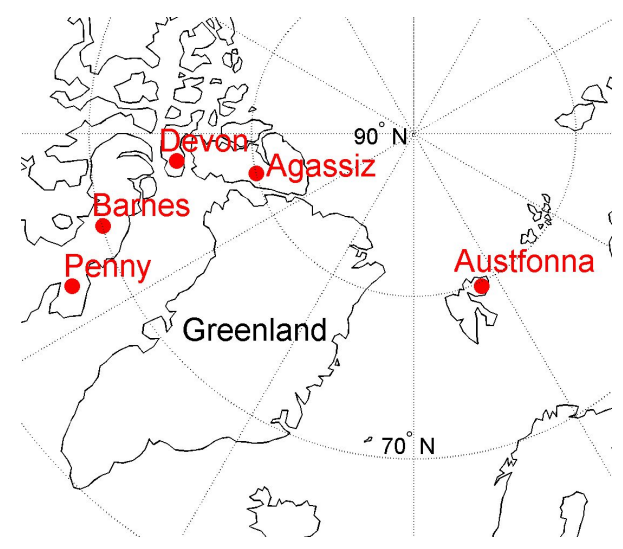

Figure 1. Location of the five ice caps measured in this study.

these ice caps have less surface reference data, they are quite different and represent a good test of the capability of the CS2 system.

\subsection{The Devon Ice Cap}

Occupying $\sim 12000 \mathrm{~km}^{2}$ of eastern Devon Island, Nunavut, the main portion of the Devon Ice Cap $\left(75^{\circ} \mathrm{N}, 82^{\circ} \mathrm{W}\right)$ ranges from sea-level, where most outlet glaciers terminate, to the ice cap summit at $\sim 1920 \mathrm{~m}$. While the ice cap loses some mass through iceberg calving (Burgess et al., 2005; VanWychen et al., 2012), the main form of ablation is through runoff, which is controlled primarily by the intensity and duration of summer melt (Koerner, 1966, 2005). Surface accumulation is asymmetric and can be as much as twice as high in the south-east compared to the northwest due to the proximity to Baffin Bay (Koerner, 1966). Surface mass balance has been negative across the northwest sector since 1960 (Koerner, 2005), but after 2005 the surface melt rates have been $\sim 4$ times greater than the long-term average (Sharp et al., 2011). This has led to a thinning of $\sim 6 \mathrm{~m}$ of the northwest basin since the sixties (Burgess, 2014). The ice cap is characterized by four glacier-facies zones that have developed at various altitudes as a function of prevailing climatic conditions (Koerner, 1970): below $\sim 1000 \mathrm{~m}$ annual melting removes all winter precipitation, creating the "ablation" zone. Above this $(\sim 1000-1200 \mathrm{~m})$, the "superimposed ice" zone develops, where refreezing of surface melt results in a net annual mass gain. In the "wet snow" zone $(\sim 1200$ $1400 \mathrm{~m}$ ) the winter snowpack experiences sufficient melt during the summer that meltwater percolates into one or more previous year's firn layers. The highest "percolation" zone typically occupies elevations above $\sim 1400 \mathrm{~m}$ to the ice cap summit, where surface melt is refrozen within the winter snowpack. It is important to emphasize that the distribution of these facies varies year-to-year, reflecting meteorological conditions and mass balance history. 


\subsection{Austfonna}

Occupying $\sim 8100 \mathrm{~km}^{2}$ of Nordaustlandet, Svalbard, Austfonna $\left(79^{\circ} \mathrm{N}, 23^{\circ} \mathrm{E}\right)$ is among the largest ice caps in the Eurasian Arctic. It consists of a main dome that reaches a maximum surface elevation of $\sim 800 \mathrm{~m}$ (Moholdt and Kääb, 2012). The south-eastern basins form a continuous calving front towards the Barents Sea, while the north-western basins terminate on land or in narrow fjords (Dowdeswell, 1986). Several drainage basins are known to have surged in the past (Dowdeswell et al., 1986), including Basin-3 which entered renewed surge activity in autumn 2012 (McMillan et al., 2014b; Dunse et al., 2015).

Mass balance stakes indicate an equilibrium line altitude (ELA) of $\sim 450 \mathrm{~m}$ in the $\mathrm{NE}$ and $\sim 250 \mathrm{~m}$ in the SE of Austfonna (Moholdt et al., 2010). This reflects a typical asymmetry in snow accumulation with the southeastern slopes receiving about twice as much precipitation as the northwestern slopes, as the Barents Sea to the east represents the primary moisture source (Pinglot et al., 2001; Taurisano et al., 2007; Dunse et al., 2009).

Despite a surface mass balance close to zero (2002-2008), the net mass balance of Austfonna has been negative at $-1.3 \pm 0.5 \mathrm{Gt} \mathrm{a}^{-1}$ (Moholdt et al., 2010), due to calving and retreat of the marine ice margin (Dowdeswell et al., 2008). Sporadic glacier surges, as currently seen in Basin-3 (McMillan et al., 2014b; Dunse et al., 2015) can significantly alter the calving flux from the ice cap. Prior to the surge of Basin3 , interior thickening at rates of $\sim 0.5 \mathrm{~m} \mathrm{a}^{-1}$ and marginal thinning of $1-3 \mathrm{~m} \mathrm{a}^{-1}$ had been detected from repeat airborne (1996-2002; Bamber et al., 2004) and satellite laser altimetry (2003-2008; Moholdt et al., 2010). The accumulation area comprises an extensive superimposed ice and wet snow zone, and in some years a percolation zone may exist. The distribution of glacier facies varies significantly from year to year, a consequence of large inter-annual variability in total amount of snow and summer ablation (Dunse et al., 2009). Despite mean annual temperatures of $-8.3^{\circ} \mathrm{C}$, large temperature variations occur throughout the year and it is not uncommon for temperatures above $0^{\circ} \mathrm{C}$ and rain events to occur in winter (Schuler et al., 2014).

\subsection{Barnes Ice Cap}

Barnes Ice Cap $\left(70^{\circ} \mathrm{N}, 73^{\circ} \mathrm{W}\right)$ is a near-stagnant ice mass that occupies $\sim 5900 \mathrm{~km}^{2}$ of the central plateau of Baffin Island. It terminates at a height of $\sim 400-500 \mathrm{~m}$ around most of its perimeter, and its surface rises gradually towards the interior, reaching a maximum elevation of $\sim 1100 \mathrm{~m}$ along the summit ridge (Andrews and Barnett, 1979). Insitu surface mass balance measurements (1970-1984), indicate winter accumulation rates of $\sim 0.5 \mathrm{~m} \mathrm{a}^{-1}$ snow water equivalent (s.w.e.), and net balance for the entire ice cap of $-0.12 \mathrm{~m} \mathrm{a}^{-1}$ (Sneed et al., 2008). Mean mass loss rates have become increasingly negative $\left(-1.0 \pm 0.14 \mathrm{~m} \mathrm{a}^{-1}\right)$ up to the present (Abdalati et al., 2004; Sneed et al., 2008; Gardner et al., 2012). In the past accumulation occurred primarily as superimposed ice (Baird, 1952), but more recently summer melt has been extensive and the ice cap has lost its entire accumulation area (Dupont et al., 2012). Similar to glaciers in the Queen Elizabeth Islands (Koerner, 2005), the surface mass balance of the Barnes Ice Cap is driven almost entirely by the magnitude and duration of summer melt (Sneed et al., 2008).

\subsection{Agassiz Ice Cap}

Agassiz Ice Cap $\left(80^{\circ} \mathrm{N}, 75^{\circ} \mathrm{W}\right)$ occupies $\sim 21000 \mathrm{~km}^{2}$ of the Arctic Cordillera on north-eastern Ellesmere Island. It ranges in elevation from sea-level, where several of the major tidewater glaciers that drain the ice cap interior terminate, to $\sim 1980 \mathrm{~m}$ at the central summit. Ice core records acquired from the summit region indicate that melt rates since the early 1990's are comparable to those last experienced in the early Holocene $\sim 9000$ years ago (Fisher et al., 2011). In situ measurements of surface mass balance indicate a long term ELA of $\sim 1100 \mathrm{~m}$ with an average accumulation rate of $0.13 \mathrm{~m}$ w.e. $\mathrm{a}^{-1}$ over the period 1977 -present. Between the summit and the sea level outlet glaciers there is a progression of ice facies similar to that described for the Devon Ice Cap.

Repeat airborne laser altimetry surveys conducted in 1995 and 2000 indicate zero change to slight thickening at high elevations, but the ice loss at lower elevations led to an estimate of ice cap wide thinning of $\sim 0.07 \mathrm{~m} \mathrm{a}^{-1}$ (Abdalati et al., 2004). More recently (2004-2009), model results confirmed by independent satellite observations (Gardner et al., 2011) suggest the ice cap has been thinning by $0.23 \mathrm{~m} \mathrm{a}^{-1}$.

\subsection{Penny Ice Cap}

Penny Ice Cap $\left(67^{\circ} \mathrm{N}, 66^{\circ} \mathrm{W}\right)$ occupying $\sim 6400 \mathrm{~km}^{2}$ of the highland region of southern Baffin Island, ranges in elevation from 0 to $1980 \mathrm{~m}$ and contains one main tidewater glacier, the Coronation Glacier, which calves into Baffin Bay (Zdanowicz et al., 2012). A historical climate record derived from deep and shallow ice cores (Fisher et al., 1998, 2011) indicates that current melting on Penny is unprecedented in magnitude and duration for the past $\sim 3000$ years. Thickness changes derived from repeat airborne laser altimetry surveys in 1995 and 2000 indicate an average ice cap wide thinning rate of $0.15 \mathrm{~m} \mathrm{a}^{-1}$, with a maximum thinning of $\sim 0.5 \mathrm{~m} \mathrm{a}^{-1}$ in the lower ablation zones (Abdalati et al., 2004). More recent measurements (2007-2011) indicate thinning of $\sim 3-$ $4 \mathrm{~m} \mathrm{a}^{-1}$ near the ice cap margin $(330 \mathrm{~m})$, amongst the highest rates of glacier melt in the Canadian Arctic (Zdanowicz et al., 2012). The current climate regime limits accumulation to elevations above $\sim 1450 \mathrm{~m}$, where it forms as superimposed ice and saturated firn. Recently, the temperature of the nearsurface firn (10 m depth) in the summit region has increased 
by $10^{\circ} \mathrm{C}$ as a result of latent heat release due to increased amounts of summer melt water refreezing at depth (Zdanowicz et al., 2012).

\section{Methods}

\subsection{CS2 SARIn data processing}

All available SARIn L1b data files (processed with ESA "baseline B" software; Bouzinac, 2014) from July 2010 to the end of December 2014 were obtained from ESA for each ice cap. Although developed independently, our processing methodology to derive geocoded heights from the L1b data is similar to that described by Helm et al. (2014), so the summary below focuses on the differences between the two methods.

Delay Doppler processing (Raney, 1998) has been completed in the down-loaded data and the resulting waveform data are included in the ESA L1b files. However, geophysical results, e.g. terrain footprint height and position, have not been calculated. Our processing for this stage has been developed primarily for the ice cap data acquired above, and the steps are illustrated in Fig. 2. The waveform data for each along-track position (time histories of the power, phase and coherence) include the unique "point-of-closestapproach" (POCA) followed in delay time by the sum of surface and subsurface returns from both sides of the POCA (Gray et al., 2013).

An initial examination of the L1b data showed that the received power waveforms varied in both shape and magnitude, and that the peak return did not necessarily follow immediately after the first strong leading edge of the return signal. This complexity is not entirely unexpected and arises due to the nature of the surface being measured, in particular the possible variation of the illuminated area at the sampling times in the receive window, and the possibility of reflections from sub-surface layers. The problem is then to identify an optimum algorithm (the "retracker") to pick the position of the POCA from the waveform. Our approach estimates the POCA position by identifying the maximum slope on the first significant leading edge of the waveform. This is similar to the approach of Helm et al. (2014), who used a particular threshold level on the first significant leading edge of the power waveform.

The choice of the threshold level retracker used by Helm et al. (2014) for their work in Greenland and Antarctica followed that of Davis (1997), who advocated a threshold retracker to help minimize the influence of subsurface returns on the detected elevation. Limited tests on some of the ice caps in our study have shown that a threshold retracker also produces satisfactory results but still does not totally eliminate the problem of a variable bias between the detected elevation and the physical surface. In contrast to the interior of Antarctica where near surface melt is very rare, in this study

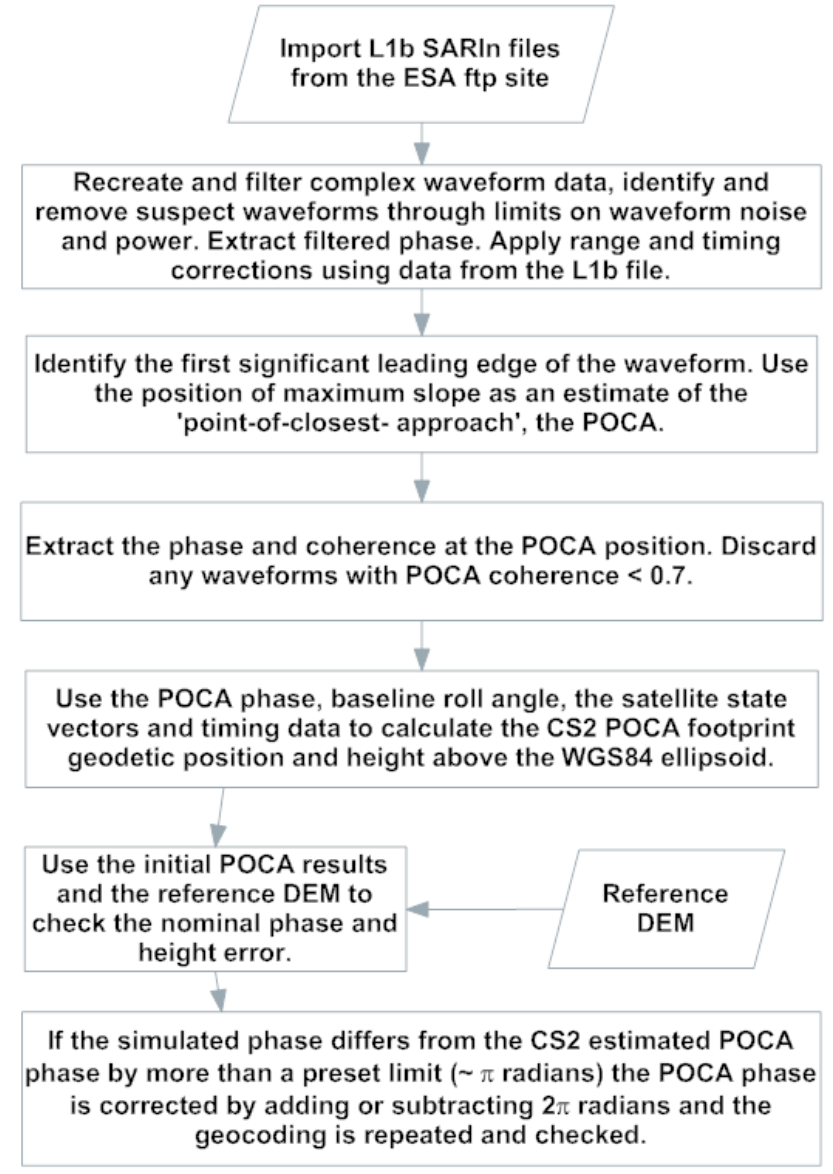

Figure 2. Flow chart showing the methodology developed to derive terrain elevation from the L1b SARIn files.

we are dealing with surface and near-surface conditions in which there are significant spatial and temporal variations in surface roughness, near surface permittivity, and microwave penetration. Consequently, it is hard to envisage that any retracker would respond to the physical surface independently of the conditions of the near surface. This issue is discussed further below in the light of the airborne and CS2 results for particular ice caps, but it is doubtful that an optimum retracker exists for all conditions.

Smoothed phase (Gray et al., 2013; Helm et al., 2014) and information on the interferometric baseline are used to estimate the unit vector in the "CryoSat-2 reference frame" (Wingham et al., 2006) pointing towards the POCA in the cross-track swath: initially the phase is used to calculate the look direction with respect to the line connecting the centres of the two receive antennas (the interferometric "baseline") using the calibration provided by Galin et al. (2012). The spacecraft attitude is then used to estimate the look direction to the POCA in the cross-track plane with respect to the nadir direction, perpendicular to the WGS84 ellipsoid. Using the data provided on satellite position and delay times, the latitude, longitude and elevation of the POCA footprints 
Table 1. Ice Cap information.

\begin{tabular}{|c|c|c|c|c|c|}
\hline & Devon & Austfonna & Barnes & Agassiz & Penny \\
\hline Location & $75^{\circ} \mathrm{N}, 82^{\circ} \mathrm{W}$ & $79^{\circ} \mathrm{N}, 23^{\circ} \mathrm{E}$ & $70^{\circ} \mathrm{N}, 73^{\circ} \mathrm{W}$ & $80^{\circ} \mathrm{N}, 75^{\circ} \mathrm{W}$ & $67^{\circ} \mathrm{N}, 66^{\circ} \mathrm{W}$ \\
\hline Size $\left(\mathrm{km}^{2}\right)$ & 12000 & 8100 & 5900 & 21000 & 6400 \\
\hline Elevation range $(\mathrm{m})$ & 0-1920 & $0-830$ & $400-1102$ & $0-1980$ & $0-1980$ \\
\hline Current glacier facies & $\begin{array}{l}\text { Ablation, } \\
\text { superimposed ice } \\
(\mathrm{SI}), \\
\text { wet snow, } \\
\text { percolation }\end{array}$ & $\begin{array}{l}\text { Ablation, } \\
\text { SI, } \\
\text { wet snow }\end{array}$ & $\begin{array}{l}\text { Ablation, } \\
(\mathrm{SI})\end{array}$ & $\begin{array}{l}\text { Ablation, } \\
\text { SI, } \\
\text { wet snow, } \\
\text { percolation }\end{array}$ & $\begin{array}{l}\text { Ablation, } \\
\text { SI, } \\
\text { wet snow }\end{array}$ \\
\hline DEM & $\mathrm{CDED}^{1}$ & U. Oslo ${ }^{2}$ & $\mathrm{CDED}^{1}$ & $\mathrm{CDED}^{1}$ & $\mathrm{CDED}^{1}$ \\
\hline Validation data & $\begin{array}{l}\text { SMB stakes, } \\
\text { surface GPS } \\
\text { profiles, } \\
\text { NASA ATM*, } \\
\text { ESA ALS*, } \\
\text { AWS }\end{array}$ & $\begin{array}{l}\text { SMB stakes, } \\
\text { surface GPS and } \\
\text { GPR profiles, } \\
\text { ESA ALS*, } \\
\text { AWS }\end{array}$ & & $\begin{array}{l}\text { SMB stakes, } \\
\text { surface GPS } \\
\text { profiles }\end{array}$ & $\begin{array}{l}\text { SMB stakes, } \\
\text { surface GPS } \\
\text { profiles }\end{array}$ \\
\hline $\begin{array}{l}\text { Approx. } 2 \text { day westward } \\
\text { orbit drift }(\mathrm{km})\end{array}$ & 25 & 15 & 34 & 15 & 38 \\
\hline $\begin{array}{l}\text { Average no. of CS } 2 \text { height } \\
\text { estimates per } 30 \text { days/per } 1 \text { year }\end{array}$ & $1350 / 16000$ & $2500 / 30000$ & $1000 / 12300$ & $670 / 8100$ & $530 / 6300$ \\
\hline $\begin{array}{l}\text { Mean elevation of CS2 } \\
\text { height estimates }\end{array}$ & $1260 \mathrm{~m}$ & $530 \mathrm{~m}$ & $900 \mathrm{~m}$ & $1588 \mathrm{~m}$ & $1530 \mathrm{~m}$ \\
\hline $\begin{array}{l}\text { Estimated elevation change } \\
\text { accuracy; high temporal } \\
(\sim 30 \text { day) resolution }\end{array}$ & $0.5 \mathrm{~m}$ & $0.5 \mathrm{~m}$ & $0.35 \mathrm{~m}$ & $\mathrm{n} / \mathrm{a}^{* *}$ & $\mathrm{n} / \mathrm{a}^{* *}$ \\
\hline $\begin{array}{l}\text { Estimated elevation change } \\
\text { accuracy; year-to-year }\end{array}$ & $0.25 \mathrm{~m}$ & $0.35 \mathrm{~m}$ & $0.2 \mathrm{~m}$ & $0.25 \mathrm{~m}$ & $0.35 \mathrm{~m}$ \\
\hline
\end{tabular}

* scanning laser altimeters. ${ }^{* *}$ n/a is not applicable. ${ }^{1}$ CDED; Canadian Digital Elevation Data: http://www.pancroma.com/downloads/NRCANCDED_specs.pdf. DEMs derived from 1:50000 and 1:250000 maps based on historical imagery. ${ }^{2}$ DEM derived from ERS 1-day repeat-pass interferometry and refined with ICESat laser altimeter data (Moholdt and Kääb, 2012).

above the WGS84 ellipsoid are then calculated. The results are checked against a reference DEM elevation (Table 1), if the difference is large, typically $50-100 \mathrm{~m}$, then the elevation and position is recalculated with the phase changed by $\pm 2 \pi$ radians. If one of these options corresponds satisfactorily to the reference DEM, and the expected cross-track slope, then the original results are replaced. In this way some of the blunders which arise with an ambiguous phase error are avoided. Note the criterion for identifying $2 \pi$ phase errors and subsequent data replacement depends on the quality of the reference DEM (Table 1).

\subsection{Determination of temporal change in surface elevation}

At the latitude of the Agassiz or Austfonna ice caps there is a westward drift of $\sim 15 \mathrm{~km}$ every 2 days in a sub-satellite track of ascending or descending CS2 orbits, increasing to 25,34 and $38 \mathrm{~km}$ at the latitudes of the Devon, Barnes and Penny ice caps respectively (Table 1). The repeat orbit period of CS2 is 369 days, with a 30-day orbit sub-cycle. Consequently, the passes over the ice caps tend to group such that there is a period in the 30-day orbit sub-cycle with relatively good coverage and a period with no coverage. The shortest practical time period for height change estimation is then the 30 day orbit sub-cycle, and while we refer to a 30 day or monthly height change variation it is important to note that data are acquired only for a fraction of the 30-day period dependent on the size of the area and the latitude. In some cases passes are missing and the data from two groups are combined to provide an adequate sample.

The average CS2 height change for a particular area between the two time periods is estimated as follows: initially each point (the centre of a CS2 footprint) in one time period is compared to the positions of all the points in the other time 
period on a point-by-point basis. If the distance between the points is within the preset limit (usually $400 \mathrm{~m}$ ), the height difference is stored and corrected for the slope between the two footprint centres using the reference DEM. When all the height differences are collected the mean and standard deviation (SD) are calculated and any pair with a height difference greater than $\sim 10 \mathrm{~m}$ from the mean (which is larger than $3 \mathrm{SD}$ - standard deviations) is discarded. The mean and standard deviation are recalculated and stored. This is done for all the possible time period combinations. The choice of $400 \mathrm{~m}$ is rather arbitrary but represents a compromise between the need for a large data sample and the increasing errors that arise as the separation between the two footprints increases. This approach has the advantage that if an unrealistic height difference is encountered it can be easily rejected. In this way we can study the monthly average height change, or select a much longer period, e.g. the period from November to May, to study the year-to-year average height change. If the total CS2 data set is large ( $>\sim 60000$ points) it may be possible to define sub areas, e.g. different elevation bands or areas with different accumulations for the monthly temporal height change analysis.

For the monthly height change we can compare all the time periods to the initial time period. However, it is possible to improve on this approach and use all the possible height differences between all the different time periods: when we compare the heights between time periods $T_{1}$ and $T_{2}$, and $T_{1}$ and $T_{3}$, we use a different subset of measurements in time period $T_{1}$. Therefore we can create a new estimate of the average height difference between $T_{1}$ and $T_{2}$ by calculating the height difference between $T_{1}$ and $T_{3}$ and adding the height difference between $T_{2}$ and $T_{3}$ if the time period $T_{3}$ precedes $T_{2}$, or subtracting if $T_{3}$ is subsequent to $T_{2}$. With $N$ separate time periods there will be $N-1$ estimates of height difference for any pair of time periods. Combining the different estimates to create a weighted average not only reduces noise but also allows a way of estimating the statistical error. This approach is a variation of the method described by Davis and Segura (2001) and Ferguson et al. (2004).

Summer melt (measured as surface elevation decrease) and winter accumulation (measured as surface elevation increase) are extracted from these time series. We assume that CS2 returns acquired in summer, if melt extends across the entire ice cap, are dominated by surface backscatter and that at this time the CS2 detected elevation change therefore reflects the true surface height change (it will be seen later that our results support this assumption). In this case summer melt can be estimated by differencing the early and late summer heights; yearly elevation change can be estimated by differencing successive minimum summer heights; and winter accumulation could be estimated by differencing the late summer height in 1 year with the early summer height the next year. However, the uncertainty in these estimates will be high, particularly because of the relatively small number of data samples possible in monthly periods.
Finally, year-to-year elevation change is calculated in the same manner but now based on a much larger data sample: typically all the data acquired between November and April or May in 1 year are compared to all the data in the same time period in subsequent years. Again, each footprint in one winter period is compared to all the footprints in the other winter time period and if the separation of footprint centres is within $400 \mathrm{~m}$ the height difference is obtained and corrected for the slope between the footprint centres. This provides a large data set, normally many thousands of height changes, and avoids the effect of the possibly large or poorly sampled summer seasonal height variation. Also, if any particular height change is unrealistically large, greater than $\sim 4 \mathrm{SD}$ from the mean, it can be removed before final averaging. In most cases the winter-to-winter approach gives a better estimate of year-to-year height change compared to differencing successive minimum summer heights, particularly if the winter meteorological conditions are comparable. This is a consequence of the advantage obtained by averaging the many samples obtained over the larger time period in comparison to the fewer acquisitions possible in the monthly time period, which are then noisier and may not capture the true minimum surface elevation. However, a change in the bias between the detected CS2 elevation and the physical surface for the different winters is still a possibility and all the available information, including field and meteorological records, should be considered.

\section{Data validation and error estimation}

Before describing the ice cap height change results, we begin in this section by comparing elevations derived from CS2 with surface elevations acquired from airborne scanning laser altimeters and kinematic GPS transects, and then address the accuracy and precision of the CS2 results. Ideally we would like to measure the surface elevation so we treat the difference as a height error and address it on three scales; the accuracy of any one CS2 elevation measurement, the accuracy of elevations averaged over an area and time period, and thirdly, elevation change estimates when averaged and differenced over various spatial and time frames.

\subsection{The difference between CS2 and surface elevations}

We use data collected over Devon and Austfonna as the surface elevation reference data. In spring 2011 an extensive skidoo-based GPS survey ( 42 by $6 \mathrm{~km}$ ) provided detailed surface height data over a relatively wide area on Devon. These ground-based data were combined with the spring 2011 NASA ATM (airborne topographic mapper) and ESA ALS (airborne laser scanner processed by the Technical University of Denmark) data to give the Devon reference surface elevation data set. The airborne data sets were first referenced to the surface GPS data, and in both cases the 
standard deviations of the differences were $<15 \mathrm{~cm}$. The positions of the surface reference data and the centres of the CS2 footprints collected between January and May 2011 are illustrated in Fig. 3 by black and blue dots respectively. For each CS2 elevation the closest reference height was found. If the distance between the reference point and the centre of the CS2 footprint was less than $400 \mathrm{~m}$, the height difference was obtained and corrected for the slope between the two positions using the reference DEM. Although the CS2 data reflect a relatively large footprint $(\sim 380 \mathrm{~m}$ along-track by $\sim 100-1500 \mathrm{~m}$ across-track, dependent on slopes) in comparison to the essentially point measurements from the reference data set, the mean of over 700 height differences (CS2 elevation minus the reference elevation) was $-0.13 \mathrm{~m}$ with a standard deviation of $1.7 \mathrm{~m}$ (Fig. 4a). In spring 2012 NASA repeated some of the 2011 flight lines and a similar methodology was used to compare the ATM laser elevations against the January to May 2012 CS2 elevations. In this case the mean height difference was $-0.22 \mathrm{~m}$ with a similar standard deviation (Fig. 4b). All of the CS2 data were acquired when the surface temperatures were below zero so we expect that, if calibrated correctly, the CS2 detected elevation would be lower than the actual surface elevation due to the expected volume component to the $\mathrm{CS} 2$ returns.

Similar results were obtained in the comparison of surface and CS2 elevations for Austfonna. Again, the surface reference data were collected in the spring before any significant melt. Airborne laser (ALS) data were collected over Austfonna in spring 2011 and 2012, and surface kinematic GPS in every spring since CS2 was launched. Some of the results are summarized in Fig. $4 \mathrm{c}$ and d. The standard deviation of the CS2 minus surface elevation differences for the 2 years 2011 and 2012 were comparable to the results for Devon; $1.5 \mathrm{~m} \mathrm{(2011)}$ and $1.8 \mathrm{~m} \mathrm{(2012),} \mathrm{but} \mathrm{the} \mathrm{mean} \mathrm{height} \mathrm{differ-}$ ences were larger; $-0.51 \mathrm{~m}$ (2011) and $-0.65 \mathrm{~m}$ (2012).

Figure 5 illustrates the individual bias points (CS2 - surface height) plotted against the elevation at which they were obtained. The median elevation for each data set is marked and the mean bias for elevations above and below the median elevation are plotted with red markers. This shows that the bias between the surface and the CS2 elevation increases with elevation, particularly for Austfonna. In summary, under cold conditions any one CS2 elevation estimate will likely be lower than the surface elevation, but the bias between the surface and the CS2 elevation can be dependent on the conditions of the particular ice cap.

\subsection{Error estimation}

The average bias between the CS2 and surface elevations changed between 2011 and 2012 for both the Devon and Austfonna data sets. Are these changes from 2011 to 2012 ( -0.13 to $-0.22 \mathrm{~m}$ for Devon and -0.51 to $-0.65 \mathrm{~m}$ for Austfonna) significant, or just a reflection of possible errors in the methodology? If each estimate is uncorrelated and part

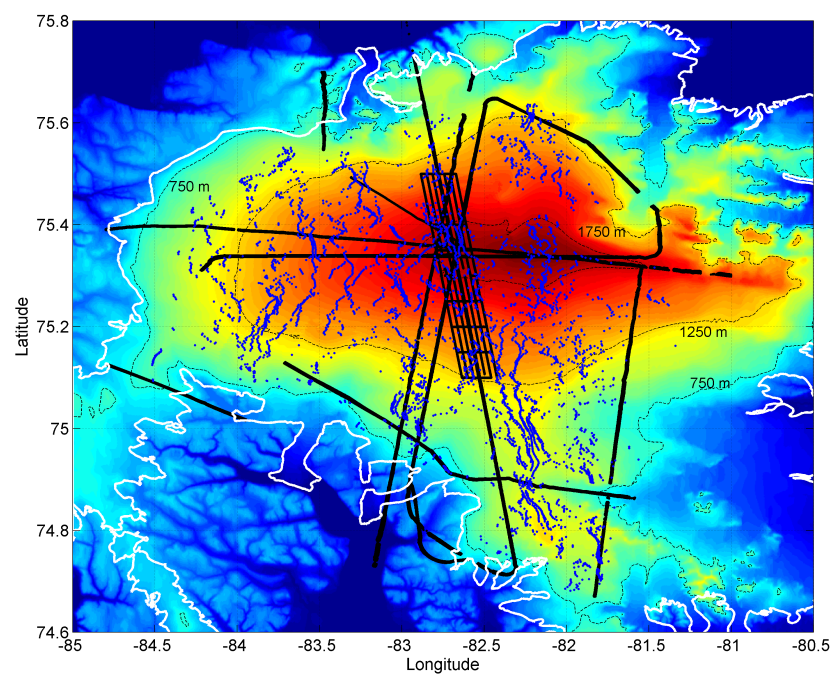

Figure 3. Digital elevation model of Devon Ice cap showing the positions of the spring 2011 reference surface elevations (in black) and the CS2 elevations (in blue) acquired between 1 January and the end of May 2011. The rectangular grid over the ice cap summit was collected from ground-based kinematic GPS surveys while the remaining transects were collected by ESA and NASA airborne missions. The white line indicates the approximate outer limit of glacial ice.

of a normal distribution, then the precision of the average can be estimated using the standard error of the mean; the standard deviation of individual estimates divided by the square root of the number of estimates in the average. This leads to an estimate of $\sim 0.06-0.07 \mathrm{~m}$ for the standard error of the means, implying that the year-to-year differences may be significant, and that there may have been some difference in the conditions year-to-year that led to the changing bias. However, the histograms in Fig. 4 appear asymmetric so that the standard error may give an optimistic error estimate because the factors contributing to the spread in the results are not necessarily uncorrelated.

When we consider the errors in average height and height change we need to consider the following aspects:

1. Changes in near-surface physical characteristics: the CS2 signal will reflect from the surface if it is wet (e.g. summer), but can penetrate the surface if it is cold and dry (e.g. winter). Changing meteorological conditions; accumulation, storms, heavy snow falls, etc., could change the bias between the CS2 detected surface and the true surface, even during the winter. We expect that the magnitude of this variable bias may be dependent on the winter accumulation and the variability in conditions.

2. Temporal sampling: the CS2 data acquisition occurs only on some of the days in each short, approximately 30 day, time period so that if monthly elevations are 

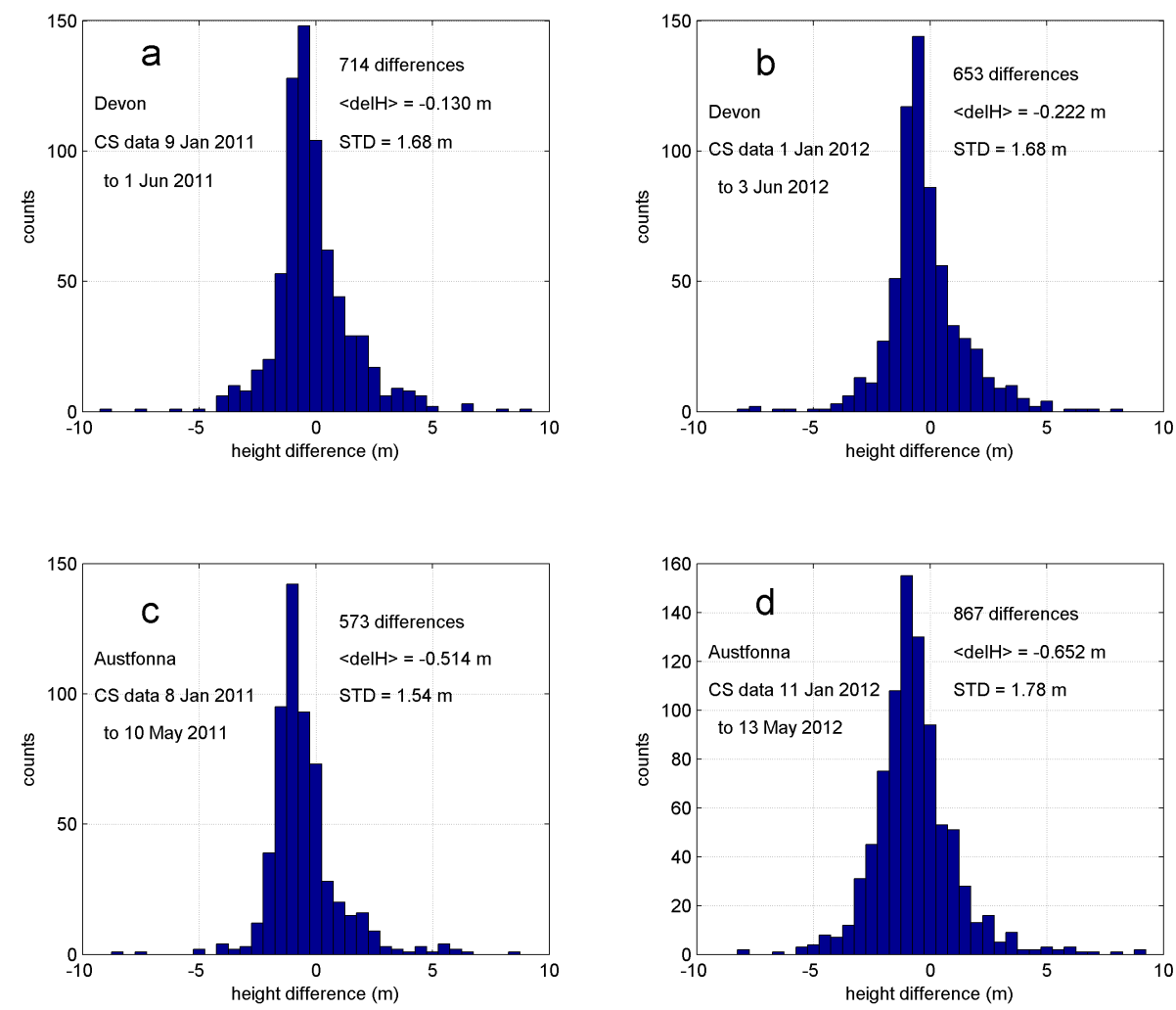

Figure 4. Histograms of the height differences, CS2 minus the reference elevations, acquired for Devon (a 2011, and b 2012) and Austfonna (c 2011 and d 2012). In the figures $<$ delH $>$ is the mean CS2 - reference elevation.

studied, some rapid changes, e.g. due to summer melt, may be poorly sampled. This error can be estimated for each location based on the slope of the summer height change and normally should be less than $\sim 20 \mathrm{~cm}$.

3. Spatial sampling - hypsometry: CS2 preferentially samples ridges and high areas since these are frequently the POCA position. Consequently, depressions and lowelevation regions will be undersampled. This can be corrected when a DEM is available because we know both the ice cap hypsometry and the distribution of elevations used for the CS2 average height change.

4. Spatial sampling - glacier facies: the height estimates may not uniformly sample the various glacier facies. As we cannot assume a constant bias between CS2 and the surface elevations for the different ice facies, the nonuniform sampling may lead to an additional error. These errors are difficult to quantify, but can be addressed on an ice-cap to ice-cap basis.

5. Altimetric corrections: there may be small systematic bias errors related to factors such as signal strength and surface slope, together with inaccuracies in atmospheric corrections.
The question remains; how well does the CS2 height change data reflect the surface height change? And what are the errors in any height change estimation? In general, these errors have to be addressed on an ice-cap to ice-cap basis. The sampling errors, 2 to 4 , will be greatest for the 30 day height changes due to the smaller sample sizes used, and should be small for year-to-year elevation change estimates when many thousands of points are averaged. Likewise, the noise and uncertainty in the CS2 results increases when analysing separate regions due to the use of fewer points than from the ice cap as a whole. When estimating year-to-year elevation change the error associated with a possible year-to-year bias change is likely less than the combined contributions of the temporal and spatial sampling for the 30 day data set that would occur by, for example, considering end of summer height from year-to-year.

In summary, although the standard deviation (SD) of CS2 estimates in relation to the surface elevation was $\sim 1.7 \mathrm{~m}$ for the Devon Ice Cap and Austfonna in the springs of 2011 and 2012, care should be taken in generalizing this result. The histograms (Fig. 4) appear asymmetric and the standard error of the mean may give an optimistic error estimate for an average of CS2 elevations over a specific area and time period. Of course, when considering an elevation change, the bias between the surface and the CS2 elevation is unimpor- 

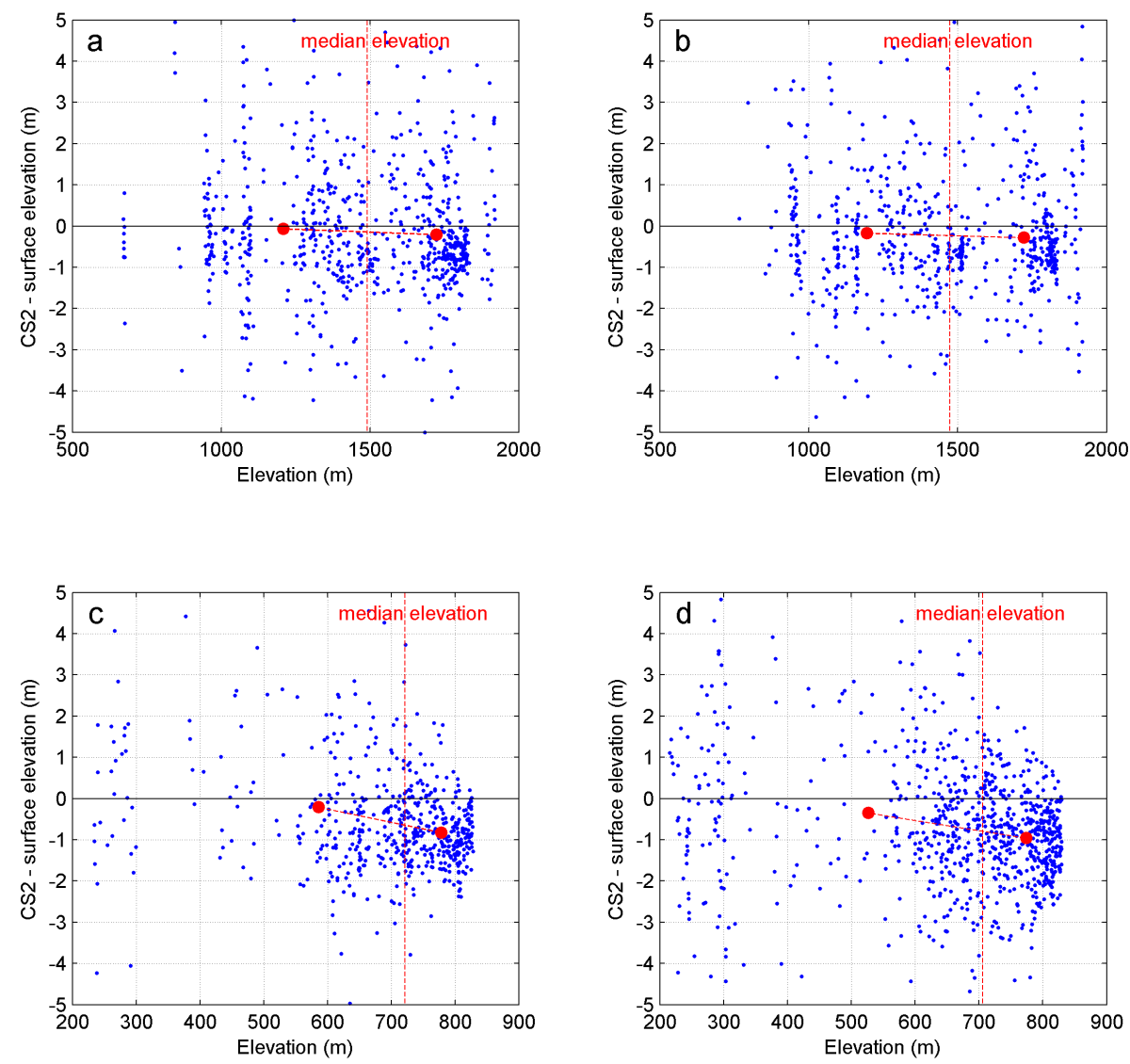

Figure 5. Biases between CS2 elevations and adjacent reference heights plotted against elevation for Devon (a 2011 and b 2012) and Austfonna (c 2011 and d 2012). The red markers indicate the average biases above and below the median elevation.

tant as long as it has not changed in the time period between the two averages. The 0.09 and $0.14 \mathrm{~m}$ differences between the CS2 data and the reference data in 2011 and 2012 for Devon and Austfonna implies that this may happen, and that the possibility cannot be ignored.

\section{Ice Cap results and discussion}

In this section we present CS2 elevation results, first for Devon Ice Cap, using them to illustrate the elevation changes over time, and the correlation with independent surface elevation measurements and temperature data from sensors on an automatic weather station (AWS). Comparisons are also made with airborne Ku-band altimeter results. The same approach is used when interpreting the height change data from the other ice caps.

\subsection{Devon Ice Cap}

We use $\sim 60000$ CS2 elevation estimates over the Devon Ice Cap acquired from June 2010 to the end of December 2014 (Fig. 6). The separation into the NW (blue) and SE (maroon) sectors allows a comparison of regions with different average accumulation. Although there are clear dips in the CS2 elevations during the two warm summers in 2011 and 2012, it is apparent that some of the CS2 elevation changes do not follow the AWS relative surface height change measurements during the cold winter-spring period (Fig. 7a and b). Indeed for the 2012-2013 winter the CS2 heights decrease from October to April when, as shown by the height sensor, the surface height change should be relatively stable. While there is a slow downslope component of the AWS sensor movement, this explains just part of the discrepancy. Also, in FebruaryMarch 2014 there is a dip in the CS2 derived height which is unlikely to be real.

The apparent differences between the CS2 and surface elevations suggest that under freezing temperatures the bias between the physical surface and the derived CS2 height does change with meteorological conditions. The variation in backscattered power with position and depth of penetration recorded by the CReSIS Ku-band altimeter flown in both 2011 and 2012 shows that the waveforms vary significantly year-to-year at the same position, and in any one year with changing position (Fig. 8). In particular, the maximum return need not be from the snow surface but could be from the ice layer associated with the previous summer melt. It is 


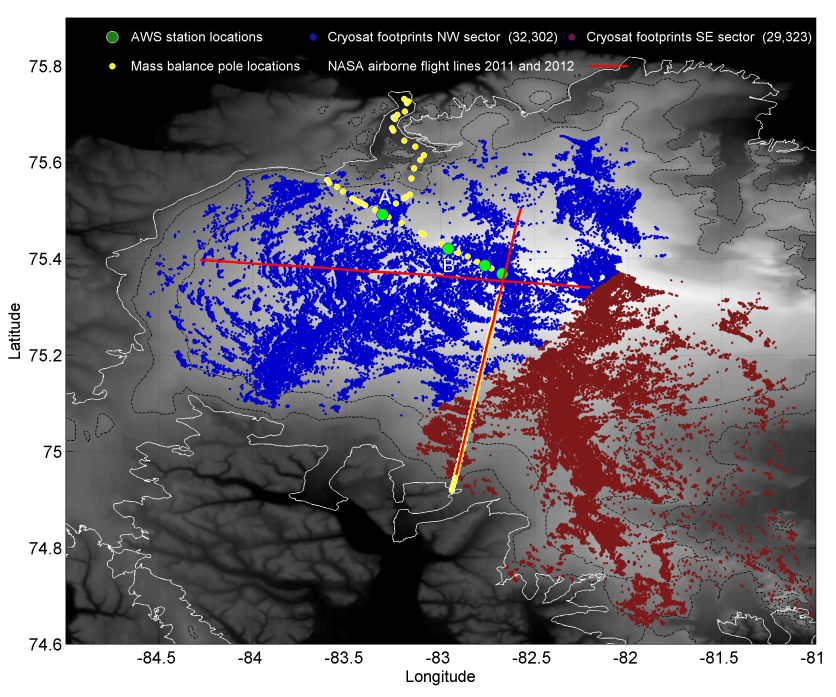

Figure 6. The coloured dots indicate the over 60000 positions for which height data have been calculated superimposed on a grey scale representation of the Devon topography. Points for the NW and SE sectors are coloured dark blue and maroon respectively. The positions of the four automatic weather stations are indicated by the green dots and the mass balance pole positions are marked as yellow dots. Data from AWS "A" and "B" are included in Fig. 7. NASA acquired airborne $\mathrm{Ku}$ altimeter data (Fig. 8) over the flight lines marked in red in both 2011 and again in 2012.

important to recognize that while the airborne altimeters can see subsurface layers it is very unlikely that the CS2 altimeter could resolve these features. The reason is not just the higher resolution of the airborne systems but rather the large difference in the footprint size. In general, the shape of the leading edge of the CS2 return waveform is related to the time rate of change of illuminated area (controlled essentially by the topography), and the relative surface and volume backscatter. The link between the CS2 waveform shape and the ice cap topography was demonstrated by the success in simulating CS2 waveforms using only CS2 timing and position data, and the DEM produced by swath processing the CS2 data (Gray et al., 2013).

It is difficult to deconvolve the effect of surface topography and volume backscatter in traditional satellite altimetry data (Arthern et al., 2001), and the same is true for the delay-Doppler processed CS2 data. Consequently, the CS2 waveforms will be affected by the multiple layer and volume backscatter, but it is very unlikely that the CS2 could resolve the kind of layering that is visible in Fig. 8. It is possible that the changing nature of the winter accumulation reduces the surface reflectivity in relation to the volume component, such that the bias between the surface and the CS2 detected height increases during the winter. If the previous summer melt layer remains as the dominant backscatter layer then the apparent height could decrease because of firn compaction and the additional two-way path length due to the permittiv- ity of the winter snow layer. This could then contribute to the apparent decrease in surface height seen in the 2012/13 winter.

The only time period when we can be confident that the peak return is simply related to the surface height is during the summer period when the solar illumination and abovezero surface temperatures lead to snow metamorphosis, a wet surface snow layer, densification and melt. With a wet surface layer the dominant returns will be from the surface as losses increase for the component transmitted into the firn volume due to the presence of moisture.

Bearing this in mind, we can now begin to interpret the progression of CS2-derived elevation changes. In both 2011 and 2012 there was extensive summer melt across all elevations, accompanied by a clear CS2 height increase at the onset of melt (Fig. 7a). This apparent surface height increase likely reflects the transition from volume returns to a surface dominated return, rather than a real surface height increase. After the initial CS2 height increase, there was a clear decrease in CS2 height throughout the rest of the summer, coincident in time with melting temperatures and thus interpreted as representing a real surface height decrease. This surface elevation decrease can therefore provide an estimate of summer ablation and snow/firn compaction. Following on from this, accumulation can then be estimated by differencing the minimum height in one summer with the early summer peak the following year, although this requires extensive melt across the ice cap for both summers, so would apply only for the winter 2011-12 accumulation on Devon Ice Cap. The influence of changing conditions on the apparent CS2detected elevation was also observed with the low-resolution mode (LRM) data in Greenland after the extensive 2012 melt (Nilsson et al., 2015). In this work an apparent CS2 height increase was shown to be due to the creation of refrozen melt layers, and not a true surface height increase.

There is a marked contrast between the large CS2-derived height losses during the warm summers (June-August) of 2011 and 2012, compared to 2013, when there were low temperatures and little surface melt (Fig. 7c). How well the CS2 height changes represent summer melt can be assessed by comparison with the AWS and mass balance pole data. From this it is clear that the maximum in accumulation and melt occur in the SE (Fig. 7a; maroon line vs blue line). Comparing the NW CS2 height changes with those measured at the lowest AWS, which at $1317 \mathrm{~m}$ is the closest to the average height of the NW sector CS2 measurements, a good correspondence is found; $-0.72 \pm 0.5 \mathrm{~m}$ (CS2) vs. $-0.64 \pm 0.03 \mathrm{~m}$ (AWS) for 2011, and $-0.44 \pm 0.5 \mathrm{~m}$ (CS2) vs. $-0.67 \pm 0.03 \mathrm{~m}$ (AWS) for 2012.

As described in the methods section, we can minimize the uncertainties introduced by temporal and spatial sampling by considering the ice cap wide average CS2 winter elevation change (red markers in Fig. 7a). Again, we find a correspondence between the average CS2 winter elevation change with 


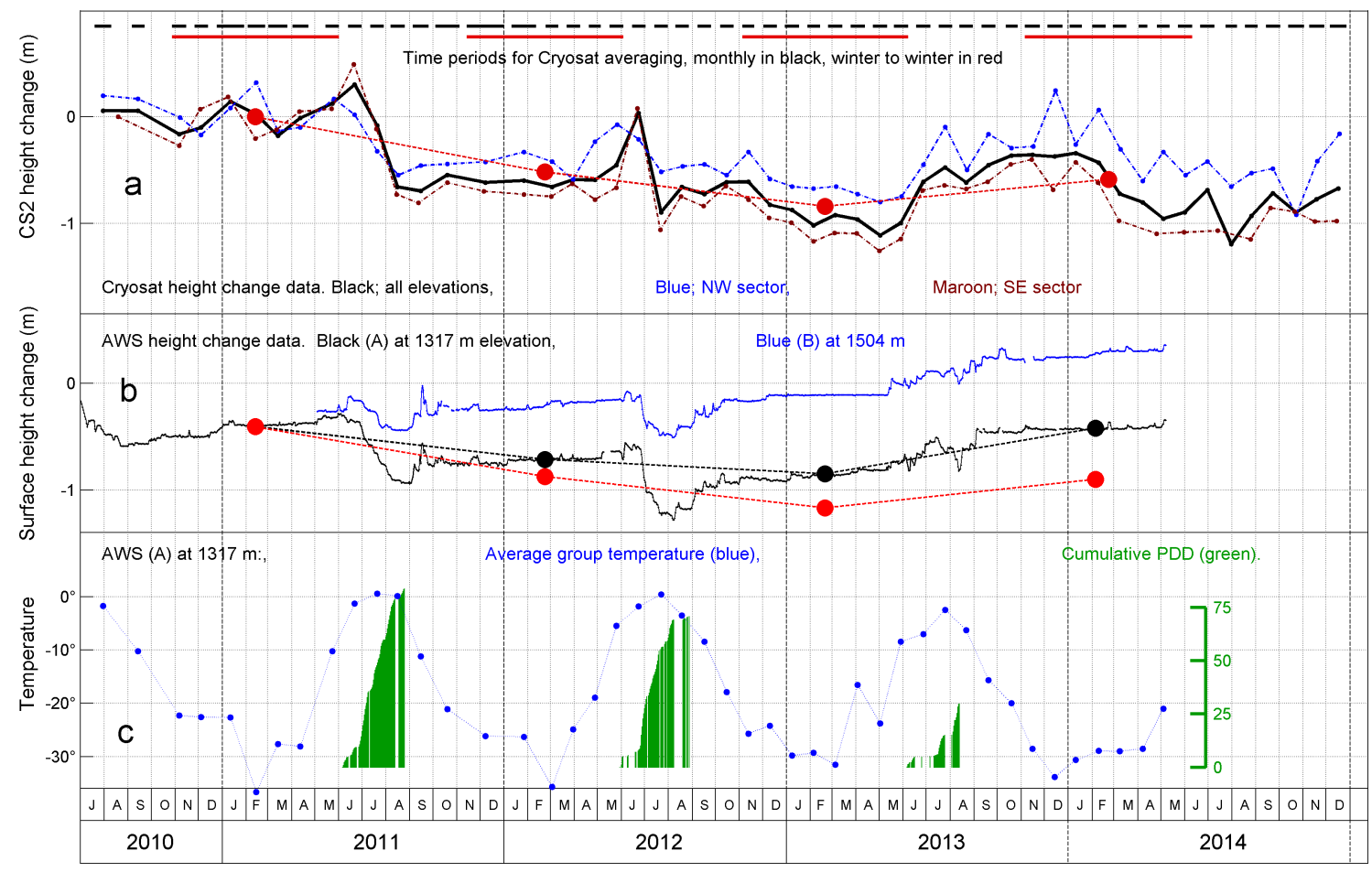

Figure 7. (a) Average CS2 height change over Devon Ice Cap as a function of time from July 2010 until December 2014 for all elevations (black), and for the NW (blue) and SE (maroon) sectors shown in Fig. 6. The short dashed black lines at the top indicate the time periods encompassing the CS2 passes which have been combined for the high temporal resolution plots. The four red dots indicate the winter-towinter height change for all the elevation data for the time periods shown by the horizontal red lines. (b) Surface height change recorded by an ultrasonic surface height sensor on the AWS labelled A in Fig. 6. Black dots indicate the height change averaged over the same time frames as the CS2 winter-to-winter height change. The red dots show the same data corrected for the AWS vertical displacement. (c) Average AWS temperature data at the CS2 pass times (blue dots) and the cumulative positive degree day data (green).

the surface elevation change recorded at the AWS at $1317 \mathrm{~m}$, averaged over the same period (Fig. 7b). However, because the AWS is fixed to the upper firn layers of the ice cap, it only provides a relative measure of surface height change. The red markers (Fig. 7b) indicate the AWS height change corrected for the $-0.16 \pm 0.05 \mathrm{~m} \mathrm{a}^{-1}$ vertical displacement measured by GPS between spring 2013 and 2014, and with the same correction assumed for the other years. These elevation changes now show a better correspondence with the red markers in Fig. 7a.

The 3-year elevation change as a function of elevation (Fig. 9a) for Devon was obtained by differencing closely spaced elevation measurements from two time periods; the winter of 2013/14 minus elevations from the first winter of CS2 operation (2010/11). This indicates that surface elevation decrease has been greatest at lower altitudes.

Table 1 includes the estimated accuracy of surface height change for the Devon Ice Cap based on CS2 measurements. The high temporal resolution row reflects the potential accuracy of year-to-year height change based on the monthly height estimates, and on the relative accuracy of monthly height change in the summer or winter. For Devon the errors include a possible bias change (item 1 in Sect. $4.2 ; \sim 0.2 \mathrm{~m}$ ), temporal and spatial sampling issues (items $2-4$ in Sect. 4.2 ; $\sim 0.4 \mathrm{~m}$ ) and the "altimetric" errors (item 5 in Sect. 4.2; $\sim 0.2 \mathrm{~m}$ ). Assuming these contributions are independent, the root square sum will give the overall error but it should be emphasized that these results are rounded, and are estimates. The year-to-year height change (final row) is based on the much larger winter time periods and the sampling errors are much reduced.

\subsection{Austfonna}

The CS2 data coverage of Austfonna is relatively good, due to the ice cap's high latitude and moderately sloped surface topography: over $100000 \mathrm{CS} 2$ height estimates have been used in our analysis over the CS2 time period to the end of 2014. This allows the data set to be split into three subregions with distinct mass balance characteristics, without introducing unacceptable sampling errors (Fig. 10). We define a southern (fawn) and northern (pink) region extending from the margin to $600 \mathrm{~m}$ elevation and a summit region (green) above $600 \mathrm{~m}$. Here, we exclude the area which has been strongly affected by the ongoing surge in Basin-3 (McMillan et al., 2014b; Dunse et al., 2015). 

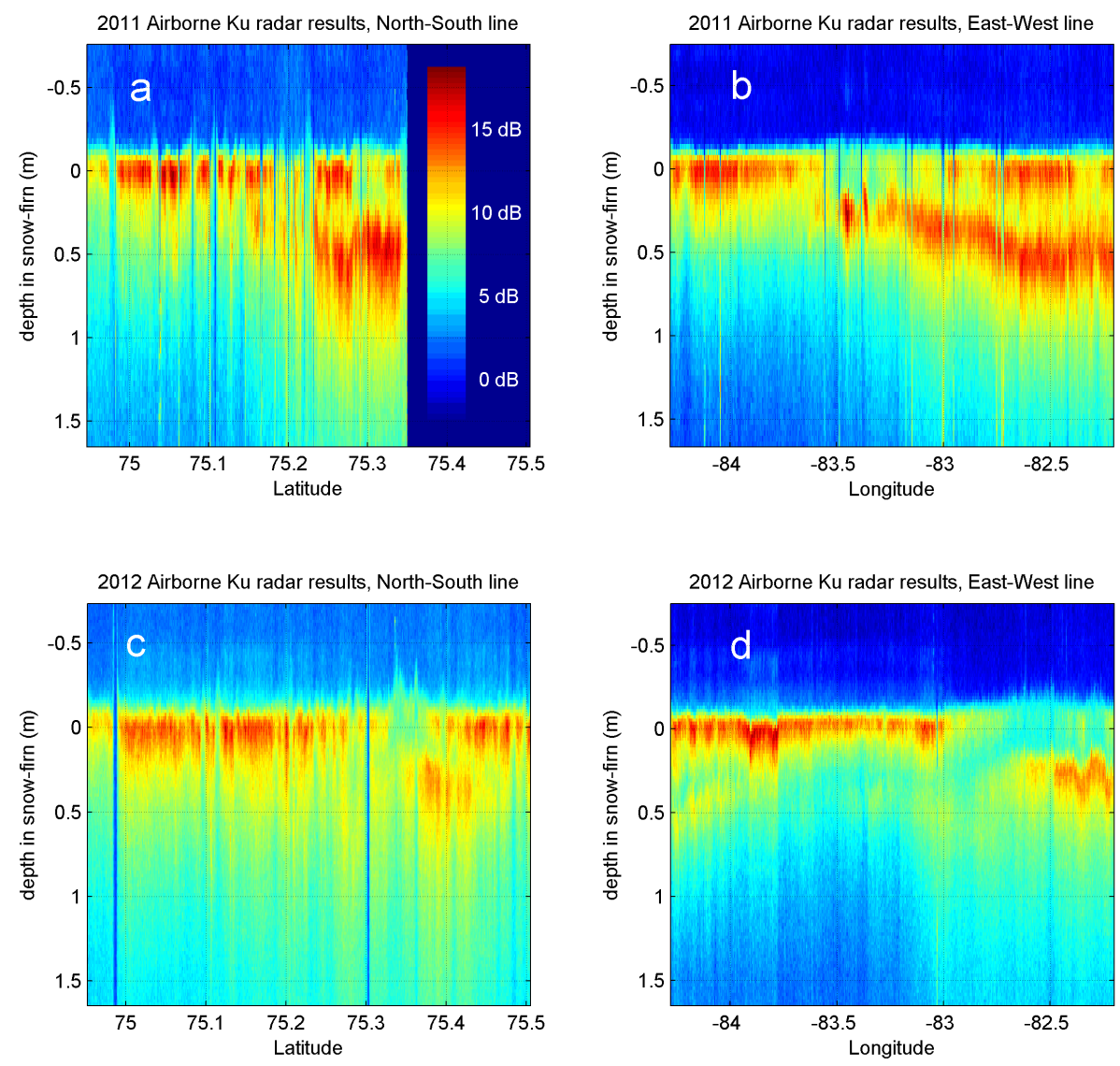

Figure 8. Variability in surface and near-surface backscatter collected over Devon Ice Cap by the CReSIS Ku band altimeter in early May in both 2011 (a, b) and 2012 (c, d). The two left panels show the 2011 and 2012 reflected power as a function of penetration into the upper snow-firn layers and position along the north-south transect shown in Fig. 6 . The two right panels show the change in return signal between the spring of 2011 and 2012 for the east-west line. A sub-surface propagation speed of $0.225 \mathrm{~m} \mathrm{~ns}^{-1}$ was assumed in preparing this figure.

The CS2 elevation change for all three regions shows a clear drop during the summer melt period (Fig. 11a), and, as expected, is smaller for the high-elevation region. The largest summer height decreases were detected in 2013. This is in agreement with spring 2014 field observations indicating very strong ablation during summer 2013, and is also reflected in the air temperature recorded by the AWS station on Etonbreen (Fig. 11b). In comparing the CS2 and AWS summer height loss data it appears that CS2 indicates less melt in the summer of 2012 than in 2011, but the three AWS surface height sensors show comparable melt. It should be noted that the positions and elevations of the AWS sensors (Fig. 10; Etonbreen, E; elevation $369 \mathrm{~m}$, Duvebreen, D; $304 \mathrm{~m}$ and Basin 3, B; $175 \mathrm{~m}$ ) may not be truly representative of the CS2 data. In particular, the average CS2 elevations for the low-elevation north and south data sets $(459$ and $380 \mathrm{~m})$ are significantly higher than the relevant AWS elevations. Consequently, it is possible that the melt at higher elevations in 2012 was really less than that in 2011.

As discussed for the Devon Ice Cap, and expected from the ASIRAS results, the fluctuations in the high temporal resolution CS2 height change data suggests that under cold conditions there can be a variable bias between the surface and CS2-derived heights. With the larger accumulation and milder, more variable winter temperatures on Austfonna one would expect the variable bias problem to be more severe than on Devon. For example, there is a large spike in elevation of 1 to $1.5 \mathrm{~m}$ between April and May 2013 for the southern low-elevation region (fawn in Figs. 10 and 11a). Data from the AWS in Basin-3 can be used to help explain this sudden jump; this indicates air temperatures in April of around $-15^{\circ} \mathrm{C}$, before warm air moves in at the beginning of May accompanied by a significant snow fall. The apparent CS2 height increase of $\sim 1-1.5 \mathrm{~m}$ over the southern coastal areas is therefore likely explained by a shift from volume to surface scatter and a real height change associated with fresh, probably wet, snow. The estimate of the error in the year-toyear CS2-based surface height change is estimated as $0.35 \mathrm{~m}$ in Table 1, larger than that for Devon because of the larger accumulation. With the high latitude the sampling issues are however less severe and the potential error in the monthly 


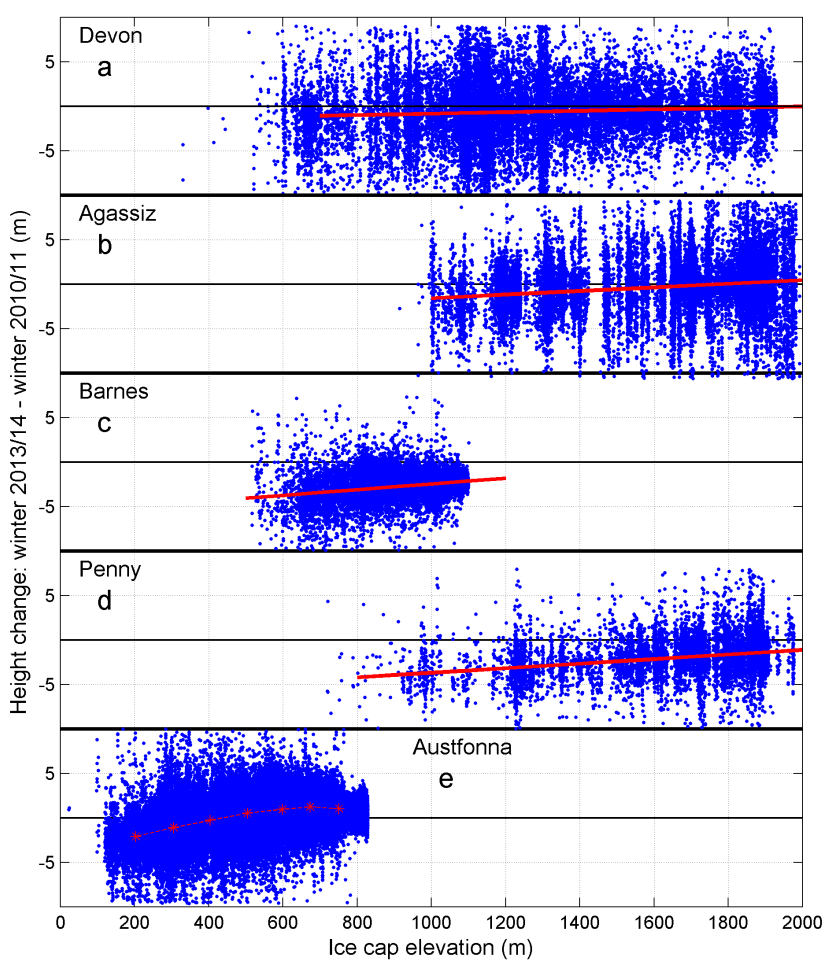

Figure 9. Height loss between the winter of 2010/11 and the winter of 2013/14 as a function of elevation for the five ice caps. Red lines are a linear fit to the data except for Austfonna (e) where the points are averages over $100 \mathrm{~m}$ elevation bands.

CS2 height in Table 1 has been estimated as $0.5 \mathrm{~m}$, the same as for Devon.

In the northern and summit region there is an overall increase in average elevation over the CS2 time frame (Figs. 11a and 12). The total winter-to-winter elevation increase for the summit region is $\sim 1 \mathrm{~m}$ over the 3 years from 2010/11 to 2013/14. This took place primarily in the first 2 years and there was little change in average high-altitude elevation between the winters of 2012/13 and 2013/14, spanning the large melt in the summer of 2013 (Fig. 11a). The northern side shows a winter-to-winter increase in elevation for the first 2 years, which then dips to an overall increase in 3 years of $\sim 0.5 \mathrm{~m}$. This dip may also be related to the large 2013 melt. In contrast, the southern region has lost elevation. This may be explained partly by the hypsometry of Bråsvellbreen (Basin 1 in Fig. 12), a surge type glacier in its quiescent phase since the last surge in 1936/37. A large fraction of the glacier lies at low elevations, and is characterized by strong ablation.

We derived the height change over 3 years by taking all the height data from the last year of data acquisition, November 2013 to December 2014, and subtracting the heights from July 2010 to December 2011 (Fig. 12). Individual pairs of height estimates within $400 \mathrm{~m}$ were differenced, slope corrected and binned into footprints of $\sim 1 \mathrm{~km}^{2}$. The most strik-

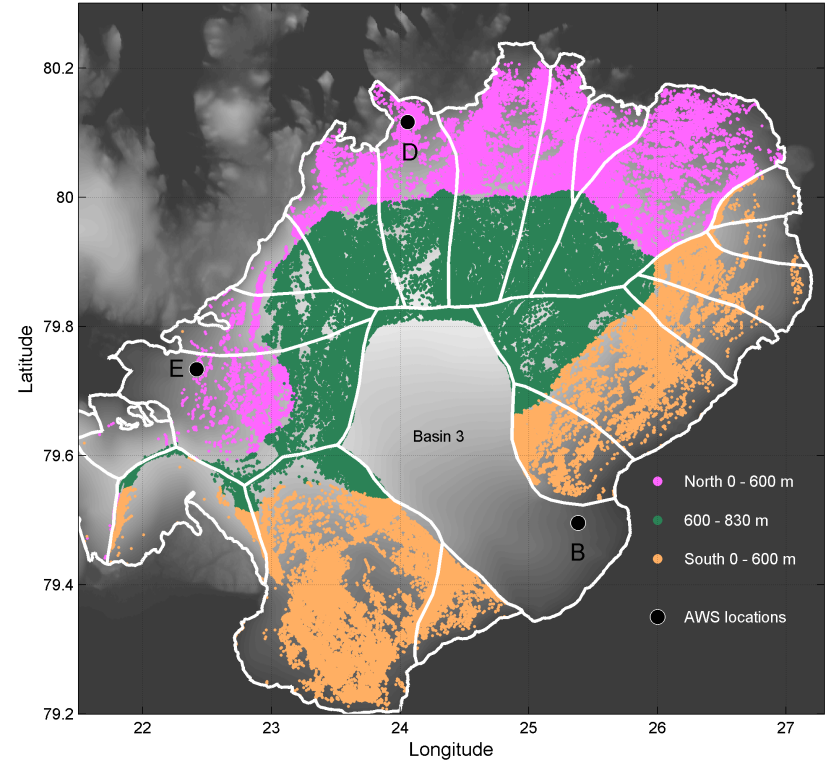

Figure 10. The different basins on Austfonna are illustrated by the white lines. Data from Basin 3, which has surged during the CryoSat-2 time period, have been removed and studied separately. The remaining CS2 data set has been split into the areas shown in different colours above, and the temporal height change plotted for both a monthly and a winter-to-winter height change in Fig. 11 below. The positions of the three automatic weather stations are marked E, D and B.

ing feature is the large height decrease of $>30 \mathrm{~m}$ associated with the surge of Basin-3. Otherwise, the pattern of interior thickening, especially along the east side of the main ice divide, and the marginal thinning resembles the elevationchange pattern reported for earlier time periods (Bamber et al., 2004; Moholdt et al., 2010). Also, the CS2 height change results are consistent with the results obtained from repeated GPS tracks (spring 2011 to spring 2014, see Fig. 12). The 3year surface height gain at elevations above $600 \mathrm{~m}$ was measured by finding pairs of surface GPS points within $1 \mathrm{~m}$ of one another, where one point was from the spring of 2011 and the other from the spring of 2014 (blue points in Fig. 12). The mean height increase was $1.19 \mathrm{~m}$ with a standard deviation of $0.32 \mathrm{~m}$. The CS2 height change was also estimated by using pairs of height estimates adjacent to the GPS transect with time windows November to April in the winters of 2010/11 and 2013/14. In this case the CS2 height increase was $0.96 \mathrm{~m}$ with a standard deviation of $1.15 \mathrm{~m}$. Although the approaches are very different this does provide added credibility that the 3-year CS2 height change illustrated in Fig. 12 does bare a strong resemblance to the surface height change.

The 3-year height loss as a function of elevation for all the Austfonna data, but with the Basin 3 data removed, mirrors the situation in Canadian Arctic ice caps (Fig. 9e). The height loss decreases with increasing elevation although the linear 


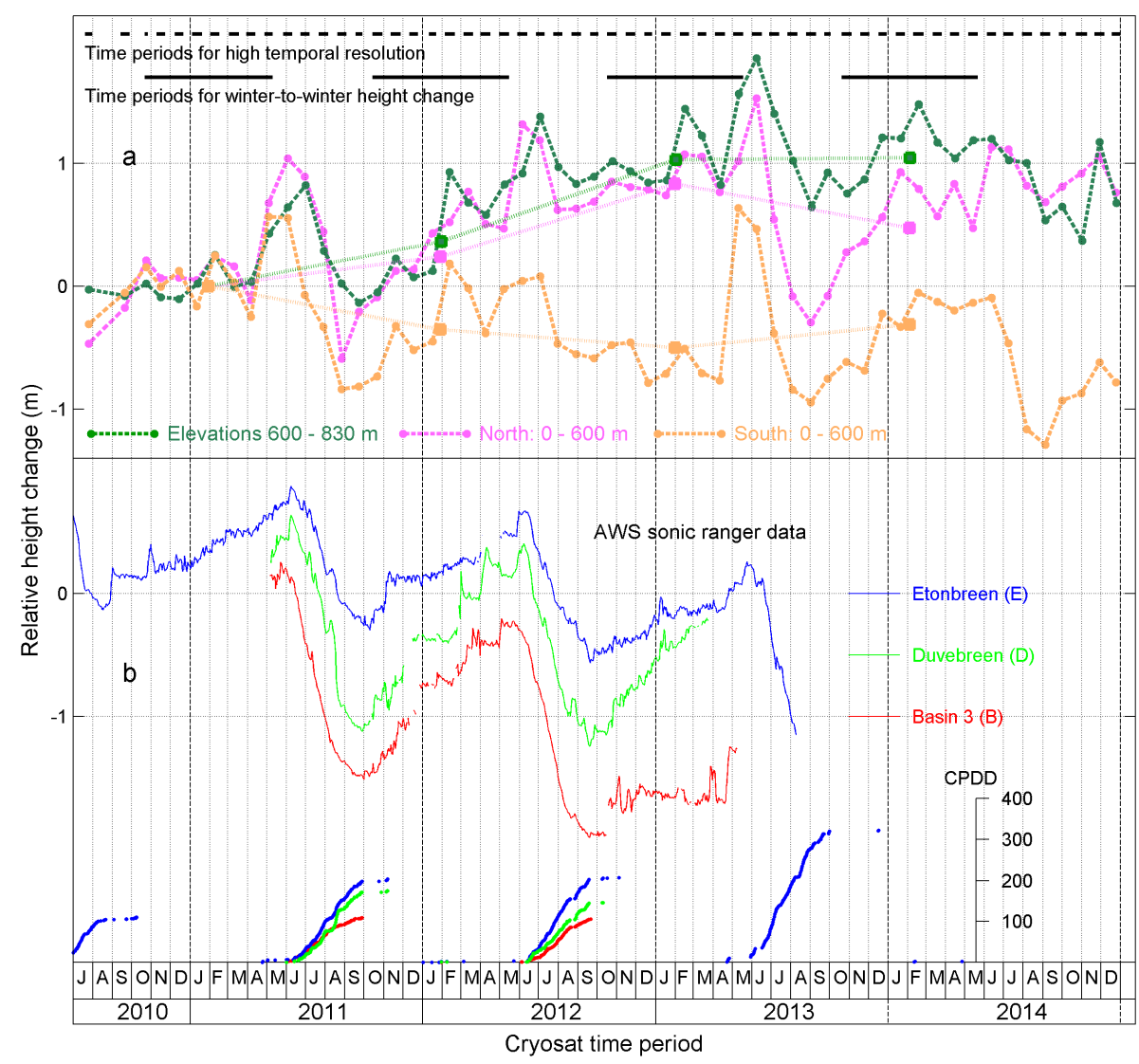

Figure 11. (a) CS2 height change plots for the three different areas illustrated in different colours in Fig. 10. The square markers indicate the height change for the larger temporal winter-to-winter time periods (October to May). Sonic ranger heights and cumulative positive degree day (CPDD) data from the 3 AWS sensors are shown in (b).

approximation used for the others is not appropriate in this case.

\subsection{Barnes Ice Cap}

On Barnes Ice Cap the relative maximum power of each return waveform shows increased power and dynamic range in the summers (Fig. 13a), which we interpret to be a consequence of significant melt and the possibility of a specular return from a wet surface. Initially moisture in the snow can reduce the backscatter but with continued melt and the creation of a wet surface there is the possibility of relatively strong coherent reflection. The 30-day CS2 height changes (Fig. 13b) clearly show significant ice loss due to the warm summers in 2011 and 2012, with much lower losses in 2013 and 2014 due to the colder summers in those years.

Each year there is a small height increase in June, immediately prior to the height loss due to summer melt (Fig. 13b). This is consistent with the observations for Devon and Austfonna, and is interpreted as the transition from a composite surface and volume signal to one dominated by the snow surface as melt begins. The height loss due to summer melt each year ranged from 1.38 to $2.55 \mathrm{~m}$, whereas winter accu- mulation, estimated from the summer minimum in one year to the maximum at the onset of melt in the following year, remained relatively constant at $\sim 1 \mathrm{~m}$ each winter. It is therefore clear from the high temporal resolution data that summer melt is dominant in defining the annual mass balance. Estimating errors is more straightforward for Barnes because of the simpler configuration of surface facies: the ice cap consists essentially of snow over ice in winter, with the loss of all the winter snow the following summer. In this case we base the error estimate on the statistics of the 50+ estimates of each height change: the error bars on the elevation change estimates (Fig. 13b) indicate \pm 2 times the standard error of the mean. This approach has not been used for the other ice caps where it might lead to an optimistic error estimate (see Table 1). As the summer melt period has increased in recent years to $\sim 87$ days (Dupont et al., 2012) the potential error in summer height loss due to melt associated with the temporal sampling is also smaller than for Devon Ice Cap.

When analysing the winter-to-winter height change results derived from the average of the December to May data each year (red dots in Fig. 13b), it is evident that between winter 2010/11 and winter 2013/14 Barnes Ice Cap 


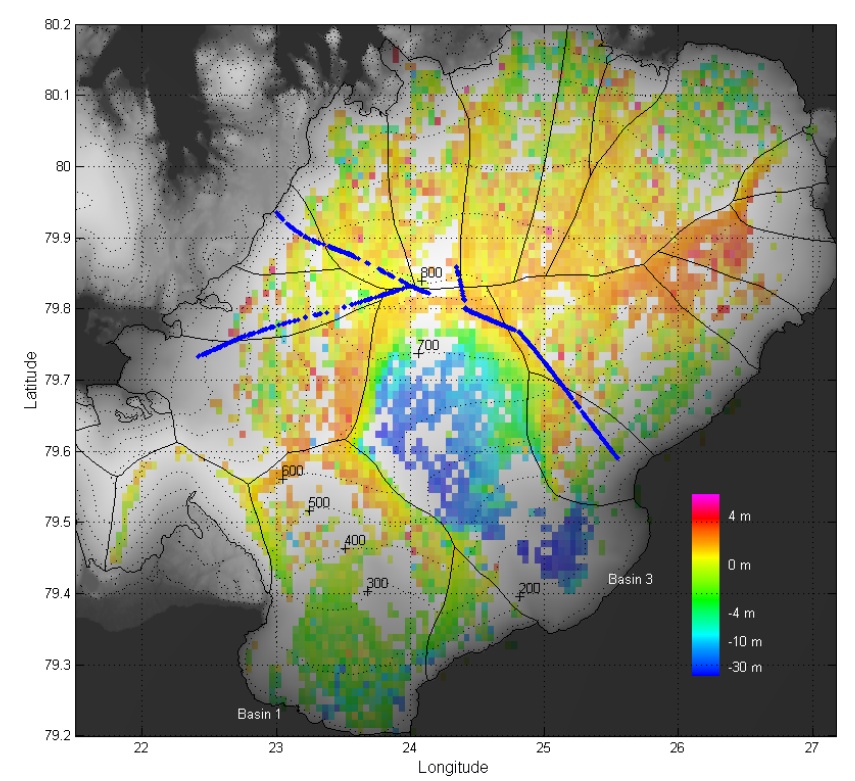

Figure 12. Three year height change estimates illustrated for different footprints across Austfonna. Each coloured pixel represents an average of the height change estimates in that footprint $\left(\sim 1 \mathrm{~km}^{2}\right)$. Note the colour scale is very nonlinear to better represent the height increase of a few metres at higher elevations, and in the northeast, and still illustrate the large height loss of $\sim 30 \mathrm{~m}$ in the lower area in basin 3 due to the surge which began in 2012. The blue dots indicate the positions where surface elevation was measured with GPS in the spring of 2011 and again in 2014.

lost $2.75 \pm 0.2 \mathrm{~m}$ in average elevation, with most of that loss occurring in the summers of 2011 and 2012. These numbers agree well with the high temporal resolution height change estimates. An increase in melt at lower elevations on the ice cap is also observed (Fig. 9c), an effect originally shown by the work of Abdalati et al. (2004) and confirmed in the work of Gardner et al. (2012).

\subsection{Agassiz and Penny ice caps}

At $81^{\circ} \mathrm{N}$ the Agassiz Ice Cap receives less accumulation and has much less summer melt than the Penny Ice Cap on southern Baffin Island $\left(67^{\circ} \mathrm{N}\right)$. The magnitudes of the peak CS2 returns reflect these different surface temperature regimes: Agassiz experienced relatively less melt than Penny Ice Cap at high elevations even in the warm 2011 and 2012 summers, consequently the seasonal variation in the peak returns is much less (Fig. 14a and b). The effect of summer melt on the CS2 returns is obvious in the Penny results (Fig. 14c and d). The strong peak returns even at high elevations at the end of July imply a strong specular reflection from a wet ice surface.

The increased time gap between the groups of passes evident for Penny in comparison to those from Agassiz is due to the fact that the ascending and descending passes over Penny occurred in the same time period, as well as the influence of the spreading of the passes due to the lower latitude.

There is little point in attempting to assess the monthly height change for either ice cap as there is simply not enough data (Table 1). However, winter-to-winter height change estimates can be made on the assumption that the conditions have not changed between each winter so that the bias between the physical surface and the CS2-detected elevation does not change. The average height change for the winters 2011/12, 2012/13 and 2013/14 with respect to the winter of 2010/11 show a larger ice loss for Penny Ice Cap in relation to Agassiz (Fig. 14e). However, the ice loss on the two ice caps, Barnes and Penny, on Baffin Island is comparable. Again the effect of the warm 2011 and 2012 summers, and the contrast with the summer of 2013, is evident. On both ice caps, height loss decreases with increasing elevation (Fig. 9).

The different climate regime between the Agassiz and Penny Ice Caps is obvious in the contrast between the plots of the peak returns in Fig. 14 (a, b vs. c, d). This implies that the bias between surface and CS2 detected surface will be less variable for Agassiz than Penny, and that the errors in surface height change will be smaller. This is reflected in the estimates of potential errors in the year-to-year height change (Table 1).

\section{Conclusions}

The airborne Ku band altimeter results over Devon Ice Cap and Austfonna imply that there will be a variable bias between the physical surface and the heights derived from CryoSat-2. This has been confirmed with our analysis of CS2 data; with ice cap wide melt the bias between the mean detected CS2 elevation and the surface elevation will be a minimum in the summer, but will increase with winter accumulation and the change in the nature of the surface. The transition from freezing temperatures to melt in the early summer is accompanied by an increase in the CS2 elevation, but without an equivalent increase in the surface height. This corresponds to the transition from a composite surface-volume backscatter to one dominated by the surface. Under freezing conditions the bias between the CS2-derived elevation and the physical surface appears to vary with the current and historical conditions on the ice cap in a way that is hard to quantify although for Austfonna the difference appears to increase with increasing elevation.

Although some of the details of the seasonal change in elevation, e.g. summer-winter, may change slightly with the form of the retracker, e.g. Ricker et al. (2015) showed some influence of the form of the retracker on sea ice freeboard results, we suspect that any CS2-detected elevation will be more dependent on the changing conditions than on the detailed form of the retracker.

Notwithstanding the uncertainty in the bias between the surface and CS2 elevation, the winter-to-winter CS2 height 


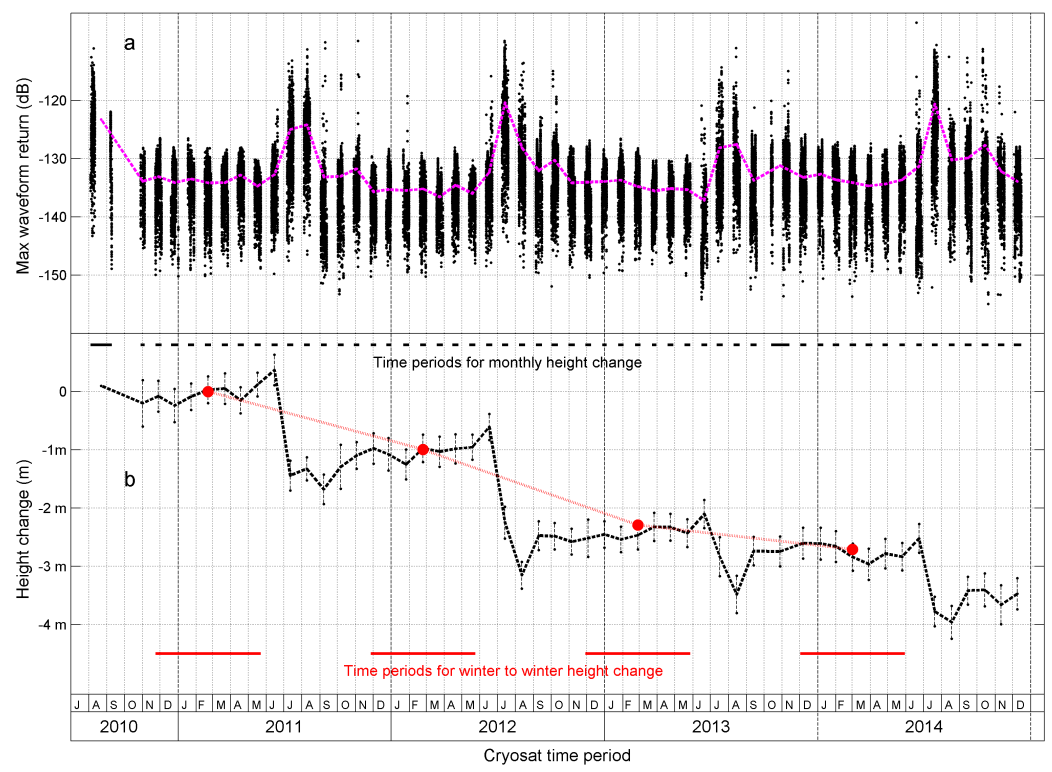

Figure 13. (a) Maximum of each of the $>44000$ waveforms from $>300$ CS2 passes over Barnes Ice Cap between 2010 and 2014 . With extensive surface melt, both the dynamic range and average POCA power (dashed purple line) increase due to the occasional strong specular reflection; (b) height change over time based on the CS2 data grouped into 55 periods, which are shown as the short dashed lines in the upper part of the panel. Red dots and dotted line indicate the winter-to-winter height change calculated from the periods represented by the four red lines at the bottom of the panel.

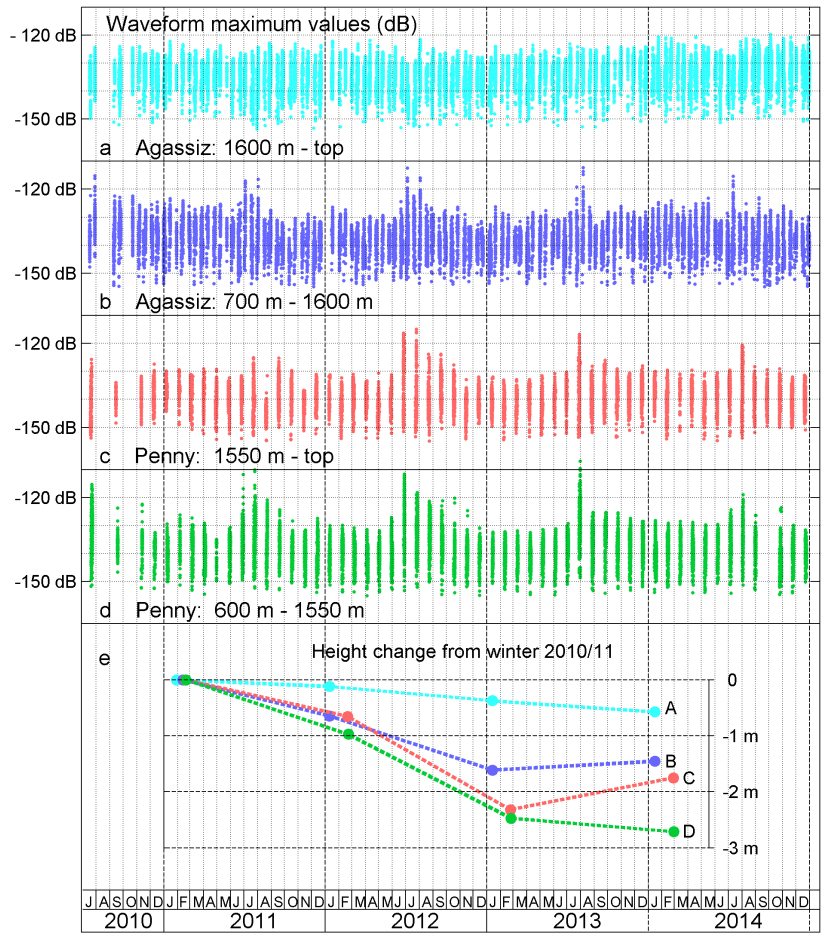

Figure 14. Waveform maxima (a-d) for two elevation ranges of the Agassiz and Penny Ice Caps. The winter-to-winter average height change for the four data groups are shown with the same colours in (e). change results can give a credible estimate of ice cap surface height change, particularly as more years are added to the time series. The largest uncertainty in these estimates, and the most difficult to quantify, comes from the fact that the conditions winter-to-winter may change in a manner that affects the bias between the surface and the CS2 elevation. Surface field measurements under cold spring conditions may help identify conditions which could lead to a changing bias between the CS2 and surface elevations. Hopefully, further work will improve the assessment of the efficacy and accuracy of using CS2 heights to measure surface height change.

The results for the Canadian ice caps show clearly the large year-to-year height decrease associated with the strong summer melt in 2011 and 2012. All show a net height loss over the CS2 time period, although Devon and Agassiz show a modest height increase after the low summer 2013 melt. This is in contrast to Austfonna where the summer of 2013 showed the largest melt-induced height loss although the upper elevations of the ice cap appears to be still gaining elevation since mid-2010 when CryoSat- 2 was commissioned. However, all the ice caps show a height loss at their lower elevations.

For the first time, CryoSat-2 has provided credible monthly height change results for some relatively small ice caps, and the summer surface height decrease has been identified and measured. For some of the ice caps this allows the estimation of both accumulation and summer melt. For Barnes, thanks to the absence of firn, the CS2 results provide an excellent record of change since the fall of 2010. The con- 
tinued loss of elevation even after the relatively cold snowy summer of 2013 attests to the eventual demise of this ice cap. In summary, we believe that the improved resolution and interferometric capability of the SARIn mode of Cryosat allows the user to identify the POCA position more accurately than with previous altimeters, and that the temporal height changes we have shown in this work depend to a large extent on the ability to better geocode the POCA footprint.

Acknowledgements. This work was supported by the European Space Agency through the provision of CryoSat-2 data and the support for the CryoVex airborne field campaigns in both the Canadian Arctic and Svalbard. NASA supported the IceBridge flights over the Canadian Arctic, while NSIDC and the University of Kansas (CreSIS) facilitated provision of the airborne laser and radar altimetry data. The Technical University of Denmark (TUD) managed the ESA supported flights over Devon and Austfonna. The IceBridge and TUD teams are gratefully acknowledged for the acquisition and provision of the airborne data used in this work. Processing of the ASIRAS instrument flown on the ESA CryoVex campaigns was done by the Alfred Wegener Institute, Bremerhaven. The Polar Continental Shelf Project (Natural Resources Canada) provided logistic support for field work in the Canadian Arctic, and the Nunavut Research Institute and the communities of Grise Fjord and Resolute Bay gave permission to conduct research on the Agassiz and Devon ice caps. Support for D. Burgess and M. N. Demuth was provided through the Climate Change Geoscience Program, Earth Sciences Sector, Natural Resources Canada and the GRIP programme of the Canadian Space Agency. Support for K. Langley was provided by ESA project Glaciers-CCI (4000109873/14/I-NB). Wesley Van Wychen and Tyler de Jong helped with the 2011 kinematic GPS survey on Devon. NSERC funding to L. Copland is also gratefully acknowledged.

We would like to thank V. Helm and the anonymous reviewer for the time and care they have taken with their reviews. Their comments have been very helpful and have improved the paper. Their contribution, and the help of the editor, E. Berthier, is gratefully acknowledged.

Edited by: E. Berthier

\section{References}

Abdalati, W., Krabill, F., Manizade, S., Martin, C., Sonntag, J., Swift, R., Thomas, R., Yungel, J., and Koerner, R.: Elevation changes of ice caps in the Canadian Arctic Archipelago, J. Geophys. Res.-Earth, 109, F04007, doi:10.1029/2003JF000045, 2004

Abdalati, W., Zwally, H. J., Bindschadler, R., Csatho, B., Farrell, S. L., Fricker, H. A., Harding, D., Kwok, R., Lefsky, M., Markus, T., Marshak, A., Neumann, T., Palm, S., Schutz, B., Smith, B., Spinhirne, J., and Webb, C.: The ICESat-2 Laser Altimetry Mission, Proc. IEEE, 98, 735-751, 2010.

Andrews, J. T. and Barnett, D. M.: Holocene (Neoglacial) moraine and proglacial lake chronology, Barnes Ice Cap, Canada, Boreas, 6, 341-358, 1979.
Arthern, R. J., Wingham, D. J., and Ridout, A. L.: Controls on ERS altimeter measurements over ice sheets: Footprint-scale topography, backscatter fluctuations, and the dependence of microwave penetration on satellite orientation, J. Geophys. Res.Atmos., 106, 33471-33484, doi:10.1029/2001JD000498, 2001.

Baird, P. D.: Method of nourishment of the Barnes ice cap, J. Glaciol., 2, 2-9, 1952.

Bamber, J., Krabill, W., Raper, V., and Dowdeswell, J.: Anomalous recent growth of part of a large Arctic ice cap: Austfonna, Svalbard, Geophys. Res. Lett., 31, L12402, doi:10.1029/2004GL019667, 2004

Bell, C., Mair, D., Burgess, D., Sharp, M., Demuth, M., Cawkwell, F., Bingham, R., and Wadham, J.: Spatial and temporal variability in the snowpack of a High Arctic ice cap: implications for mass-change measurements, Ann. Glaciol., 48, 159-170, 2008.

Bouzinac, C.: CryoSat-2 Product Handbook, Tech. Report, European Space Agency, available at: http://emits.sso.esa.int/ emits-doc/ESRIN/7158/CryoSat-PHB-17apr2012.pdf (last access: 23 September 2015), 2014.

Brandt, O., Hawley, R. L., Kohler, J., Hagen, J. O., Morris, E. M., Dunse, T., Scott, J. B. T., and Eiken, T.: Comparison of airborne radar altimeter and ground-based $\mathrm{Ku}$-band radar measurements on the ice cap Austfonna, Svalbard, The Cryosphere Discuss., 2, 777-810, doi:10.5194/tcd-2-777-2008, 2008.

Burgess, D. O.: Mass balance of the Devon (NW), Meighan, and South Melville ice caps, Queen Elizabeth Islands for the 2012-2013 balance year, Open File 7692, Geological Survey of Canada, Ottawa, Canada, p. 26, doi:10.4095/295443, 2014.

Burgess, D. O., Sharp, M. J., Mair, D. W. F., Dowdeswell, J. A., and Benham T. J.: Flow dynamics and iceberg calving rates of the Devon Island ice cap, Nunavut, Canada, J. Glaciol., 51, 219238, doi:10.3189/172756505781829430, 2005.

Davis, C. H.: A robust threshold re-tracking algorithm for measuring ice-sheet surface elevation change from satellite radar altimeters, IEEE T. Geosci. Remote, 35, 974-979, doi:10.1109/36.602540, 1997.

Davis, C. H. and Segura, D. M.: An algorithm for time-series analysis of ice sheet surface elevations from satellite altimetry, IEEE T. Geosci. Remote, 39, 202-206, 2001.

De la Pena, S., Nienow, P., Shepherd, A., Helm, V., Mair, D., Hanna, E., Huybrechts, P., Guo, Q., Cullen, R., and Wingham D.: Spatially extensive estimates of annual accumulation in the dry snow zone of the Greenland Ice Sheet determined from radar altimetry, The Cryosphere, 4, 467-474, doi:10.5194/tc-4-467-2010, 2010.

Dowdeswell, J. A.: Drainage-basin characteristics of Nordaustlandet ice caps, Svalbard, J. Glaciol., 32, 31-38, 1986.

Dowdeswell, J. A., Drewry, D., Cooper, A., Gorman, M., Liestøl, O., and Orheim, O.: Digital mapping of the Nordaustlandet ice caps from airborne geophysical investigations, Ann. Glaciol., 8, 51-58, 1986.

Dowdeswell, J. A., Benham, T. J., Strozzi, T., and Hagen, J. O.: Iceberg calving flux and mass balance of the Austfonna ice cap on Nordaustlandet, Svalbard, J. Geophys. Res., 113, F03022, doi:10.1029/2007JF000905, 2008.

Dunse, T., Schuler, T. V., Hagen, J. O., Eiken, T., Brandt, O., and Høgda, K. A.: Recent fluctuations in the extent of the firn area of Austfonna, Svalbard, inferred from GPR, Ann. Glaciol., 50, 155-162, 2009. 
Dunse, T., Schellenberger, T., Kääb, A., Hagen, J. O., Schuler, T. V. S., and Reijmer, C. H.: Glacier-surge mechanisms promoted by a hydro-thermodynamic feedback to summer melt, The Cryosphere, 9, 197-215, doi:10.5194/tc-9-197-2015, 2015.

Dupont, F., Dupont, F., Royer, A., Langlois, A., Gressent, A., and Picard, G.: Monitoring the melt season length of the Barnes Ice Cap over the 1979-2010 period using active and passive microwave remote sensing data, Hydrol. Process., 26, 2643, doi:10.1002/hyp.9382, 2012.

Ferguson, A. C., Davis, C. H., and Cavanagh, J. E.: An Autoregressive Model for Analysis of Ice Sheet Elevation Change Time Series, IEEE. T. Geosci. Remote, 42, 2426-2436, 2004.

Fisher, D. A., Koerner, R. M., Bourgeois, J. C., Zielinski, G., Wake, C., Hammer, C. U., Clausen, H. B., Gundestrup, N., Johnsen, S., Goto-Azuma, K., Hondoh, T., Blake, E., and Gerasimoff, M.: Penny Ice Cap, Baffin Island, Canada and the Wisconsinan Foxe Dome connection: two states of Hudson Bay ice cover, Science, 279, 692-695, 1998.

Fisher, D. A., Zheng, J., Burgess, D. O., Zdanowicz, C., Kinnard, C., Sharp, M. J., and Bourgeois, J.: Recent melt rates of Canadian Arctic Ice Caps are the highest in many millennia, Global Planet. Change, 84/85, 3-7, doi:10.1016/j.gloplacha.2011.06.005, 2011.

Galin, N., Wingham, D. J., Cullen, R., Fornari, M., Smith, W. H. F., and Abdall, S.: Calibration of the CryoSat-2 Interferometer and Measurement of Across-track Ocean Slope, IEEE T. Geosci. Remote., 51, 57-72, 2012.

Gardner, A. S., Moholdt, G., Wouters, B., Wolken, G. J., Burgess, D. O., Sharp, M. J., Cogley, J. G., Braun, C., and Labine, C.: Sharply increased mass loss from glaciers and ice caps in the Canadian Arctic Archipelago, Nature, 473, 357-360, doi:10.1038/nature10089, 2011.

Gardner, A. S., Moholdt, G., Arendt, A., and Wouters, B.: Accelerated contributions of Canada's Baffin and Bylot Island glaciers to sea level rise over the past half century, The Cryosphere, 6 , 1103-1125, doi:10.5194/tc-6-1103-2012, 2012.

Gardner, A. S., Moholdt, G., Cogley, J. G., Wouters, B., Arendt, A. A., Wahr, J., Berthier, E., Hock, R., Pfeffer, W. T., Kaser, G., Ligtenberg, S. R. M., Bolch, T., Sharp, M. J., Hagen, J. O., van den Broeke, M. R., and Paul, F.: A Reconciled Estimate of Glacier Contributions to Sea Level Rise: 2003 to 2009, Science, 340, 852-857, doi:10.1126/science.1234532, 2013.

Gray, L., Burgess, D., Copland, L., Cullen, R., Galin, N., Hawley, R., and Helm, V.: Interferometric swath processing of CryoSat-2 data for glacial ice topography, The Cryosphere, 7, 1857-1867, doi:10.5194/tc-7-1857-2013, 2013.

Hawley, R. L., Morris, E. M., Cullen, R., Nixdorf, U., Shepherd, A., and Wingham, D. J.: ASIRAS airborne radar resolves internal annual layers in the dry-snow of Greenland, Geophys. Res. Lett., 33, L04502, doi:10.1029/2005GL025147, 2006.

Hawley, R. L., Brandt, O., Dunse, T., Hagen, J. O., Helm, V., Kohler, J., Langley, K., Malnes, E., and Gda, K. H.: Using airborne Kuband altimeter waveforms to investigate winter accumulation and glacier facies on Austfonna, Svalbard, J. Glaciol., 59, 893-899, 2013.

Helm, V., Rack, W., Cullen, R., Nienow, P., Mair, D., Parry, V., and Wingham, D. J.: Winter accumulation in the percolation zone of Greenland measured by airborne radar altimeter, Geophys. Res. Lett., 34, L06501, doi:10.1029/2006GL029185, 2007.
Helm, V., Humbert, A., and Miller, H.: Elevation and elevation change of Greenland and Antarctica derived from CryoSat2, The Cryosphere, 8, 1539-1559, doi:10.5194/tc-8-1539-2014, 2014.

Jensen, J. R.: Angle measurement with a phase monopulse radar altimeter, IEEE T. Antenn. Propag., 47, 715-724, 1999.

Koerner, R. M.: Accumulation on the Devon Island Ice Cap, Northwest Territories, Canada, J. Glaciol., 6, 383-392, 1966.

Koerner, R. M.: Some observations on superimposition of ice on the Devon Island Ice Cap, N.W.T., Canada, Geogr. Ann. A, 52, 57-67, 1970.

Koerner, R. M.: Mass balance of glaciers in the Queen Elizabeth Islands, Nunavut, Canada, Ann. Glaciol., 42, 417-423, doi:10.3189/172756405781813122, 2005.

McMillan, M., Shepherd, A., Sundal, A., Briggs, K., Muir, A., Ridout, A., Hogg, A., and Wingham, D.: Increased ice losses from Antarctica detected by CryoSat-2, Geophys. Res. Lett., 41, 3899-3905, doi:10.1002/2014GL060111, 2014a.

McMillan, M., Shepherd, A., Gourmelen, N., Dehecq, A., Leeson, A., Ridout, A., Flament, T., Hogg, A., Gilbert, L., Benham, T., van den Broeke, M., Dowdeswell, J., Fettweis, X., Noël, B., and Strozzi, T.: Rapid dynamic activation of a marinebased Arctic ice cap, Geophys. Res. Lett., 41, 8902-8909, doi:10.1002/2014GL062255, 2014b.

Meier, M. F., Dyurgerov, M. B., Rick, U. K., O’Neel, S., Pfeffer, W. T., Anderson, R. S., Anderson, S. P., and Glazovsky, A. F.: Glaciers Dominate Eustatic Sea-Level Rise in the 21st Century, Science, 317, 1064-1067, doi:10.1126/science.1143906, 2007.

Moholdt, G. and Kääb, A.: A new DEM of the Austfonna ice cap by combining differential interferometry with ICESat laser altimetry, Polar Res., 31, 18460-18470, doi:10.3402/polar.v31i0.18460, 2012.

Moholdt, G., Hagen, J. O., Eiken, T., and Schuler, T. V.: Geometric changes and mass balance of the Austfonna ice cap, Svalbard, The Cryosphere, 4, 21-34, doi:10.5194/tc-4-21-2010, 2010.

Nilsson, J., Vallelonga, P., Simonsen, S. B., Sørensen, L. S., Forsberg, R., Dahl-Jensen, D., Hirabayashi, M., Goto-Azuma, K., Hvidberg, C. S., Kjær, H. A., and Satow, K.: Greenland 2012 melt event effects on CryoSat-2 radar altimetry, Geophys. Res. Lett., 42, 3919-3926, doi:10.1002/2015GL063296, 2015.

Pinglot, J. F., Hagen, J. O., Melvold, K., Eiken, T., and Vincent, C.: A mean net accumulation pattern derived from radioactive layers and radar soundings on Austfonna, Nordaustlandet, Svalbard, J. Glaciol., 47, 555-566, 2001.

Raney, R. K.: The Delay/Doppler Radar Altimeter, IEEE T. Geosci. Remote, 36, 1578-1588, 1998.

Ricker, R., Hendricks, S., Perovich, D. K., Helm, V., and Gerdes, R.: Impact of snow accumulation on CryoSat- 2 range retrievals over Arctic sea ice: An observational approach with buoy data, Geophys. Res. Lett., 42, 4447-4455, doi:10.1002/2015GL064081, 2015.

Schuler, T. V., Dunse, T., Østby, T. I., and Hagen, J. O.: Meteorological conditions on an Arctic ice cap -8 years of automatic weather station data from Austfonna, Svalbard, Int. J. Climatol., 34, 2047-2058, doi:10.1002/joc.3821, 2014.

Sharp, M., Burgess, D. O., Cogley, J. G., Ecclestone, M., Labine, C., and Wolken, G. J.: Extreme melt on Canada's Arctic ice caps in the 21st century, Geophys. Res. Lett., 38, L11501, doi:10.1029/2011GL047381, 2011. 
Sneed, W. A., Hooke, R. Le B., and Hamilton, G. S.: Thinning of the south dome of Barnes Ice Cap, Arctic Canada, over the past two decades, Geology, 36, 71-74, doi:10.1130/G24013A.1, 2008.

Taurisano, A., Schuler, T. V., Hagen, J.-O., Eiken, T., Loe, E., Melvold, K., and Kohler, J.: The distribution of snow accumulation across Austfonna ice cap Svalbard: direct measurements and modeling, Polar Res., 26, 7-13, 2007.

VanWychen, W., Copland, L., Gray, L., Burgess, D., Danielson, B., and Sharp, M.: Spatial and temporal variation of ice motion and ice flux from Devon Ice Cap, Nunavut, Canada, J. Glaciol., 58, 657-664, doi:10.3189/2012JoG11J164, 2012.

Vaughan, D. G., Comiso, J. C., Allison, I., Carrasco, J., Kaser, G., Kwok, R., Mote, P., Murray, T., Paul, F., Ren, J., Rignot, E., Solomina, O., Steffen, K., and Zhang, T.: Observations: Cryosphere, in: Climate Change 2013: The Physical Science Basis, Contribution of Working Group I to the Fifth Assessment Report of the Intergovernmental Panel on Climate Change, Cambridge University Press, Cambridge, UK and New York, NY, USA, 2013.
Wingham, D., Francis, C. R., Baker, S., Bouzinac, C., Cullen, R., de Chateau-Thierry, P., Laxon, S. W., Mallow, U., Mavrocordatos, C., Phalippou, L., Ratier, G., Rey, L., Rostan, F., Viau, P., and Wallis, D.: CryoSat-2: a mission to determine the fluctuations in earth's land and marine ice fields, Adv. Space Res., 37, 841-871, 2006.

Zdanowicz, C., Smetny-Sowa, A., Fisher, D., Schaffer, N., Copland, L., Eley, J., and Dupont, F.: Summer melt rates on Penny Ice Cap, Baffin Island: Past and recent trends and implication for regional climate, J. Geophys. Res., 117, F02006, doi:10.1029/2011JF002248, 2012. 